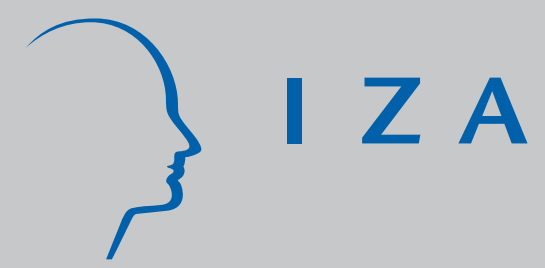

IZA DP No. 8440

Examining the Relationships between Labour Market Mismatches, Earnings and Job Satisfaction among Immigrant Graduates in Europe

Seamus McGuinness

Delma Byrne

August 2014 


\title{
Examining the Relationships between Labour Market Mismatches, Earnings and Job Satisfaction among Immigrant Graduates in Europe
}

\author{
Seamus McGuinness \\ Economic \& Social Research Institute Dublin, \\ Trinity College Dublin, NILS, Flinders University and IZA \\ Delma Byrne \\ National University of Ireland Maynooth
}

Discussion Paper No. 8440

August 2014

IZA

P.O. Box 7240

53072 Bonn

Germany

Phone: +49-228-3894-0

Fax: +49-228-3894-180

E-mail: iza@iza.org

\begin{abstract}
Any opinions expressed here are those of the author(s) and not those of IZA. Research published in this series may include views on policy, but the institute itself takes no institutional policy positions. The IZA research network is committed to the IZA Guiding Principles of Research Integrity.

The Institute for the Study of Labor (IZA) in Bonn is a local and virtual international research center and a place of communication between science, politics and business. IZA is an independent nonprofit organization supported by Deutsche Post Foundation. The center is associated with the University of Bonn and offers a stimulating research environment through its international network, workshops and conferences, data service, project support, research visits and doctoral program. IZA engages in (i) original and internationally competitive research in all fields of labor economics, (ii) development of policy concepts, and (iii) dissemination of research results and concepts to the interested public.
\end{abstract}

IZA Discussion Papers often represent preliminary work and are circulated to encourage discussion. Citation of such a paper should account for its provisional character. A revised version may be available directly from the author. 
IZA Discussion Paper No. 8440

August 2014

\section{ABSTRACT}

\section{Examining the Relationships between Labour Market Mismatches, Earnings and Job Satisfaction among Immigrant Graduates in Europe}

This paper uses graduate survey data and econometric methods to estimate the incidence and wage/job satisfaction effects of over-education and overskilling among immigrants graduating from EU 15 based universities in 2005. Female immigrants with shorter durations of domicile were found to have a higher likelihood of overskilling. Newly arrived immigrants incurred wage penalties' which were exacerbated by additional penalties resulting from overskilling in the male labour market and overeducation in the female labour market. Established immigrants were found to enjoy a wage premia, particularly within the male labour market, with no evidence of disproportionate wage impacts arising as a consequence of mismatch. Female immigrants were generally found to have a significantly lower probability of being job satisfied relative to native female graduates.

JEL Classification: J31, J61

Keywords: overeducation, overskilling, immigrants, pay, job satisfaction

Corresponding author:

Seamus McGuinness

Economic and Social Research Institute

Whitaker Square

Sir John Rogerson's Quay

Dublin 2

Ireland

E-mail: Seamus.McGuinness@esri.ie 


\section{Introduction}

To date, the position of immigrants in the labour market has attracted considerable attention within the literature (Lindley, 2009; Kucel and Byrne, 2008; Dex and Lindley, 2007; Battu and Sloane, 2004; Alpin et al., 1998; Blackaby et al., 1998, 1999, 2002, 2005; Bell, 1997; Duncan and Hoffman, 1981; Chiswick, 1980). These studies have produced conflicting findings regarding the labour market outcomes of immigrant groups. On the one hand, a body of work has empirically demonstrated that immigrants and specific ethnic minority groups occupy an unequal and disadvantaged position in the labour market in terms of higher unemployment rates, lower earnings and higher rates of overeducation (Blackaby et al., 1998, 1999, 2002, 2005; Duncan and Hoffman, 1981; Alpin et al., 1998; Battu and Sloane, 2004; Kucel and Byrne, 2008; Messinis, 2008a, 2008b; Lindley, 2009, Nelison, 2011). However, a number of studies have also found that, on average, immigrants perform better than natives in the home labour market in terms of both higher employment and earnings (Bell, 1997; Clark and Lindley, 2005). Nevertheless, within those studies reporting that immigrants perform better, clear ethnic differences exist, with non-white immigrants tending to perform poorly relative to both white natives and white immigrants (Clark and Lindley, 2005).

Explanations for higher rates of educational mismatch among immigrants tend to centre on labour market discrimination. If immigrant groups find it more difficult to acquire a suitable job, they may well be more likely to take a job that is not commensurate with their qualifications, resulting in higher proportions becoming overeducated. With the level of educational attainment rising amongst immigrant groups as a whole, discrimination, if reflected in greater levels of mismatch and thus lower earnings and job satisfaction, may place doubts on the importance of human capital attainment as an avenue for escaping disadvantage (Leslie and Drinkwater, 1999). In contrast, others argue that such differentials in levels of mismatch may be observed without necessarily attributing this to labour market discrimination (Lindley, 2009). There may be differences in the 'quality' of education received in terms of subjects, grades and institutions attended (Bhattacharoversk, Ison and Blair 2003; Jones and Elias, 2005), while in many studies, differences in language skills are not observed. Furthermore, immigrant education may be location specific with respect to their home labour market, which will also impact on levels of labour market progression within the host labour market.

This paper contributes to the current immigration literature on a number of levels. To begin with, it considers and compares the labour market position of immigrants and natives within a group of European countries using high quality graduate cohort data. Furthermore, it is arguably free of many of the biases associated with previous studies in relation to (a) quality differences in the education of immigrants, (b) location specific human capital effects and (c) 
unobserved language differences. That is, it considers the outcomes of graduates from European universities who have stayed to work in the country of graduation post-study.

Immigration research has consistently pointed to the importance of the location in which the human capital was acquired; in the country of origin or in the host country. To date, a small number of studies have emphasised the differential returns to location-specific human capital, with human capital that is acquired in the host country demonstrating higher returns (Bell, 1997; Shields and Wheatley Price, 1998). While previous studies may have restricted exploration of the labour market position of immigrant minority groups to those who have attained native qualifications (see for example Lindley, 2009), this study provides a more ready comparison of a homogenous population, comparing like with like, by focusing on similarly agedlexperienced entrants to graduate labour market. Furthermore, as the graduates in this study have successfully completed third-level qualifications in the host country, we can confidently assume that language difficulties are no longer a factor. The paper also extends the literature on the labour market position of immigrants with respect to both education and skill mismatch. Finally, this research provides more rigorous econometric testing of labour market outcomes in relation to the incidence of mismatch, wages and job satisfaction. Few studies have accounted for selectivity bias or unobserved heterogeniety and, while arguably, such factors are less of an issue within such a relatively homogenous sample, it is still important that they are considered (for exceptions see Blackaby et al., 2002).

In terms of labour market outcomes, our primary goal is to determine the degree to which immigrants experience higher rates of job mismatch relative to natives and the extent to which such exposures exacerbate existing differentials with respect to both earnings and job satisfaction.

\section{Data and Methods}

The Flexible Professional in the Knowledge Society (REFLEX) project was financed as a Specific Targeted Research Project (STREP) of the European Union's Sixth Framework Programme covering 15 countries. It is limited to graduates in the 1999/2000 academic year, who were interviewed five years later in 2005 . We focus on graduates from the EU member states of Austria, Belgium, Finland, France, Germany, Italy, Netherlands, Norway, Portugal, Spain and the UK thus excluding observations from the Czech Republic, Estonia and Japan.

To date all studies of mismatch and immigration \ethnicity have focused exclusively on overeducation, however, there is an emerging strand of literature which argues that overskilling is a much more dependable measure of mismatch (Mavromaras et al., 2010, Mavromaras et al., 2012, Mavromaras \& McGuinness, 2013 McGuinness and Wooden, 
2009). Overeducation has been criticised on the grounds that it represents a relatively imprecise measure of human capital mismatch, whereby education proxies individual human capital and job entry requirements proxy the skill requirements of the job. Clearly individual human capital can be accumulated through both formal and informal means, thus overeducation ignores skills acquired while on-the-job. Similarly, in a world of rising educational attainment and credentialism, job entry requirements represent an increasingly imprecise measure of job complexity. It has also been argued that overeducated workers may be of lower ability and that the observed pay penalty merely reflects this, suggesting that studies of overeducation are heavily affected by unobserved individual heterogeneity bias. Arguably overskilling, which directly compares actual human capital, whether that be acquired formally or informally or related to innate ability, with actual job requirements overcomes all of the measurement problems associated with overeducation and, is therefore, potentially a much more robust measure of mismatch. Within the context of studies of immigration, the use of skill mismatch is particularly advantageous as language abilities should be encompassed within individual responses, thus lessening the impacts of unobserved bias within the measure. In the data immigrant status is identified on the basis of a question on the respondents country of birth.

In terms of the individuals selected for this study, we restrict our sample to employees domiciled within EU 15 countries who were in full-time study prior to graduation. This leaves us with an effective sample of 15,005 , with individual country samples varying from 2,296 for the Netherlands to 360 in Portugal. Immigrants account for 3.31 per cent of the sample, which equates to just under 500 effective observations. There exists a substantial variation in the immigrant share across countries, ranging from under 1 per cent in Italy Portugal and Belgium to over 9 per cent in the UK, with the remaining country immigrant shares ranging from 1.7 to 4.6 per cent. It is important to reiterate that the sample is representative of the population of host educated immigrant graduates active in the native labour market, as opposed to the population of all immigrants per se. Within the data individuals were defined as overeducated if they indicated that a below tertiary level of education was most appropriate for the job. Overskilling was based on the response to a question asking individuals to rate on a 1 to 5 scale $^{1}$ the extent to which their skills and knowledge were utilised in their work with a response of 1 or 2 deemed consistent with overskilling.

An obvious advantage of our dataset is that it enables us to study the relative impacts of both overeducation and overskilling among immigrant and native graduates controlling for the effects of educational quality, location specific human capital and language difficulties. The main drawback of the data is does not allow us to disaggregate our data in terms of

1 Where 1 was 'not at all' and 5 to 'a very high extent'. 
ethnic background ${ }^{2}$. Nevertheless, we believe that the study makes an important contribution on the grounds of the uniqueness of the sample and the robustness of the estimates presented. In terms of the methods adopted, we add to the traditional analysis of this topic by including a range of checks and controls for the influences of sample selection and unobserved heterogeneity bias.

\section{Results}

Table 1 reports the incidence of graduate overeducation and overskilling within our sample of countries. At between 2 and 3 per cent, overeducation rates were lowest in Belgium and Norway and highest in Spain, the UK and Italy where rates ranged from 13 to 17 per cent. The country level distribution of overskilling was somewhat different, with Spain and France exhibiting the highest rates and Portugal and Norway the lowest. Nevertheless, with the exception of France and Belgium where the rates of overskilling substantially exceeded those for overeducation, there appears a relatively strong relationship between the incidences of overeducation and overskilling within countries. However, this is not to say that the same individuals are simultaneously identified as mismatched under each measure, in fact, we found that just 49 per cent of overeducated graduates were also overskilled, while 43 per cent of overskilled graduates where also overeducated. This reinforces the view that both measures of mismatch are likely to be very different in nature (see Mavromaras et al (2010) \& McGuinness \& Sloane (2011)), thus justifying their separate analysis with respect to their relationship with immigration status.

\section{[Insert Table 1 here]}

With respect to our multivariate analysis, we begin by assessing the extent to which immigrant graduates educated within the host country are prone to educational and skills mismatch. The data enables us to refine our definition of immigrants in some important ways; firstly; we can control for time since arrival as the questionnaire asks whether the individual lived in the host ${ }^{3}$ country at age 16. Accordingly, 65 per cent of our immigrant sample was designated as "established immigrants" with the balance subsequently referred to as "new immigrants". Secondly, the data contains information on country of origin, however, as is evident from table $A 1$, the distribution is highly dispersed and requires some aggregation to be of any use within an econometric framework. We subsequently group the country of origin variable into the following categories (a) EU 15 (b) EU accession states (c) high income countries ${ }^{4}$ and (d) the rest of the world. We begin by estimating three specifications to test for the sensitivity of the estimates to immigrant definition applied. Our models contain a range of controls related to faculty of study, years spent in higher education. field mismatch, employment history, employer characteristics and country level fixed effects. The models relate to employment status five years after graduation and the

\footnotetext{
A question on ethnicity was asked for the UK portion of the sample alone.

In this instance host country refers to the country within which the survey is conducted.

Australia, Canada, US, Switzerland and New Zealand.
} 
results for the overeducation equation are presented in table 2 .

The model reveals that an individual's single most important determinant of overeducation in current employment is overeducation in their first job, thus confirming earlier research that supports the notion of overeducation as a non-transitory phenomenon (see Mavromaras \& McGuinness, 2012). Interestingly, current overeducation was negatively associated with initial overskilling although the marginal effects are very low. With respect to the other variables in the model, overeducation was found to be positively correlated with previous unemployment and job mobility ${ }^{5}$ and inversely related to years of HE study, field mismatch, participation in a degree programme perceived as prestigious, supervisory responsibilities, hours worked, employment in an R\&D intensive firm and employment in a small firm. After accounting for such effects, relative to the base case of Germany, overeducation was higher in Italy and Austria and lower in France, the Netherland, the UK, Norway and Belgium. Regarding the mismatch variables, crucially, there was no evidence to suggest that graduates from an immigrant background were more likely to be overeducated, with the result holding when time since arrival and country of origin was controlled for.

[Insert Table 2 here]

[Insert Table 3 here]

On the grounds that relationships may vary according to gender we re-estimated the overeducation models for males and females separately (Table 3$)^{6}$. The overall immigrant variable and those controlling for time since arrival and country of origin were again insignificance. The results from tables 2 and 3 suggest that, contrary to the findings of previous research, immigrant graduates are not prone to higher risks of overeducation in models that fully control for the impacts of location specific human capital and language differences, suggesting that previous studies may have been prone, at least to some degree, to individual unobserved heterogeneity bias.

The results of the overall overskilling model are reported in Table 4. The model results are similar to those for overeducation, with overskilling in first employment again proving to be the most important determinant of current overskilling. The incidence of overskilling was found to be higher among males, older workers and those with a history of unemployment, while it was inversely related to labour market experience, field mismatch, course prestige, perceived course reputation among employers, R\&D intensity, public sector employment and having a supervisory role. With respect to country level effects, after controlling for

5 As measured by the number of previous employers. This finding supports the view that increased mobility levels among mismatched workers often result in the individual moving from one state of mismatch to another (McGuinness (2003), McGuinness \& Wooden (2009)).

6 For the purposes of brevity, we report only the key coefficients. Full results are available from the authors on request. 
individual level differences, only Finland was found to have a lower rate of overskilling relative to the base case of Germany. In contrast to overeducation, we found that immigrants were 3 per cent more likely to be overskilled relative to native graduates, with specification 2 indicating that the disadvantage relates exclusively to immigrants who had been domiciled in the host country at the age of 16 . This is certainly a somewhat surprising result on the grounds that this grouping is likely to have been the most assimilated and are also likely to have undertaken second level schooling in the host country. Finally, specification 3 shows a higher overskilling risk among immigrants from EU 15 member states. The gender specific equations (Table $5^{7}$ ) indicate that the observed effects relate specifically to female immigrants, with those domiciled within the host country at the age of 16 experiencing a 4 percent increased probability of being overskilled in employment five years following graduation (relative to native female graduates). Given that we have, arguably largely eliminated many of the usual concerns related to both the nature of acquired human capital and language competencies from our estimates, these finding raise some significant concerns with respect to labour market access among established female immigrants. As a next step, it would be useful to assess the extent to which the findings are related to ethnic minority status, however, as stated, this was not possible using this data.

We sought to check that our estimates of the incidence of overeducation and overskilling were not affected by selection bias, i.e. the possibility that the observable characteristics of immigrants were not distributed in a non-random fashion with respect to mismatch. Failure to account for such influences can result in naive probit models, such as those presented in Tables 2 to 5, generating biased estimates. Within the existing literature linking mismatch with immigrant status, the issue of selection has been largely ignored. We consequently estimate the likelihood of mismatch among immigrants relative to natives with similar observable characteristics, and thus similar probabilities of mismatch, using propensity score matching (PSM). Due to sample size problems, it was only possible to assess the robustness of the overall immigrant coefficients for males and females as any further disaggregation, according to either date of arrival or country of origin, was not feasible. The first stage of the PSM revealed that immigrants tended to be older, have fewer years labour market experience, spent fewer years in higher education and were less likely to complete a degree programme that was perceived to be prestigious. However, perhaps crucially, they were not more likely to be overeducated or overskilled in their initial employment, suggesting that they did not have a higher exposure to the key determinant of mismatch in current employment ${ }^{8}$. The results generated under the Nearest Neighbour algorithm indicate that immigrants are around 4 per cent more likely to be overskilled with the impact more pronounced within the female labour market. The PSM estimate correspond closely to the

\footnotetext{
7 For the purposes of brevity, we report only the key coefficients. Full results are available from the authors on request.

8 Results available from the authors.
} 
key estimates from the probit models, suggesting that, at least in relation to the incidence of mismatch, selection bias is not an issue (Table 6).

The reliability of any propensity score matching estimate is dependent upon the Conditional Independence Assumption ( $\mathrm{CIA}$ ) being met i.e. that selection to the treatment is based solely on observables within the dataset and that all variables that simultaneously impact both the treatment and outcome variable are also observed. Given the richness of our models, we are confident that the variables at hand sufficiently describe immigrant characteristics. Nevertheless, despite the richness of our data, it is not possible to completely rule out the possibility that our estimates are unaffected by one or more unobserved effects that simultaneously influence both the treatment and outcome variables. As a final check we ran the MHBOUNDS procedure in STATA on the overskilling estimate for all immigrants to assess its robustness to potential unobserved confounding factors that simultaneously impact the probability of both overskilling and immigrant status. We begin with the assumption of zero bias i.e. $\Gamma=1$. The intuition here is that the results are robust to unobservables that positively impact both the likelihood of immigration status and an overskilling and subsequently increase the odds ratio of immigration (termed positive selection bias) up to a factor of $1.15(\Gamma=1.15)$. Thus, while our analysis suggests that our key overskilling estimates are not prone to selection bias, it is also clear that they will relatively quickly become unreliable in the presence of any substantial unobserved confounding influence ${ }^{9}$.

$$
\begin{aligned}
& \text { [Insert Table } 4 \text { here] } \\
& \text { [Insert Table } 5 \text { here] } \\
& \text { [Insert Table } 6 \text { here] }
\end{aligned}
$$

Having established that immigrants do not have higher probabilities of overeducation but are somewhat prone to a higher risk of overskilling, we next test the hypothesis that graduates from immigrant backgrounds incur larger pay and job satisfaction penalties when overeducated and overskilled. Within the general mismatch literature a general pattern has emerged of higher pay penalties associated with overeducation relative to overskilling, with overskilling associated with a much larger negative impact on job satisfaction (Mavromaras et al, 2010). This has led some authors to conclude that an aspect of the overeducation pay differential may relate to a compensating wage differential with workers trading lower wages for other aspects of the job that enhance individual lifestyles (McGuinness \& Sloane, 2011). The large impact of overskilling on job satisfaction has led to suggestions that this represents a more genuine form of mismatch (Mavromaras et at, 2013). It is clearly necessary to examine the relative impacts of mismatch on both job satisfaction and wages in order to achieve a concise picture of the extent to which workers are being constrained by the phenomenon.

9 Results available from the authors. 
The issue of selection bias is again considered and, given that we have observed that immigrants tend to be older, have lower levels of labour market experience and less likely to have completed a prestigiously perceived degree programme, it seems that sample selection bias represents a more substantial risk in the context of the wage equation. To date, propensity score matching has been used to test the robustness of estimates of overeducation and overskilling on earnings (Mavromaras et al, $(2007,2008)$, McGuinness (2007), McGuinness \& Sloane (2011). However, given that we are interested in variations of any wage / job satisfaction penalty in terms mismatch status for immigrants relative to native, propensity score matching is no longer appropriate due to the problem of small sample size among the various treatment groups.

In addition to the problem of sample selection, the issue of unobserved heterogeneity bias has been widely discussed within the literature both within the context of education \skill mismatch and immigration. While we are confident by restricting our analyses to graduates of native universities and using of skills mismatch as a key variable we overcomes many of the usual omitted variable problems, additional checks are still undertaken. It has been argued that, within the context of graduate cohort data, where respondents tend to be very similar in terms of both their education and labour market experience profiles, that quantile regression may provide a solution to any outstanding missing variables problem (McGuinness \& Bennet (2007). Following the rationale of McGuinness \& Bennet (2007), we argue that unobserved differences in the human capital levels of (a) mismatched workers due to, for example, lower ability or (b) immigrants due, for example, to poor language skills, will be reflected in their position within the wage distribution which will reflect differences in graduates levels of human capital. By comparing the impacts of immigration and mismatch within quantiles of the graduate cohort wage (human capital) distribution, we are limiting the impacts of unobserved heterogeneity. The quantile regression model can be formally written as follows (see Buchinsky, 1994).

$$
\ln w_{i}=x_{i} \beta_{\phi}+u_{\phi i} \quad \text { with } \quad \text { Quant }_{\phi}\left(\ln w_{i} \mid x_{i}\right)=x_{i} \beta_{\phi}
$$

Where $x_{i}$ is a vector of exogenous variables. Quant ${ }_{\phi}\left(\ln w_{i} \mid x_{i}\right)$ denotes the $\phi_{t h}$ conditional quantile of $\mathrm{w}$ given $\mathrm{x}$. The $\phi_{t h}$ regression quantile, $0<\phi<1$, is defined as the solution to the problem:

$$
\min \beta \varepsilon R^{k}\left(\sum_{i: y_{i} \geq x_{i} \beta} \phi\left|\ln w_{i}-x_{i} \beta_{\phi}\right|+\sum_{i: y_{i}<x_{i} \beta}(1-\phi)\left|\ln w_{i}-x_{i} \beta_{\phi}\right|\right)
$$

The above equation is usually written as: 


$$
\min \beta \varepsilon R^{k} \sum_{i} \rho_{\phi}\left(\ln w_{i}-x_{i} \beta_{\phi}\right)
$$

Where $\rho_{\Phi(e)}$ is the check function defined as $\rho_{\Phi(e)}=\phi e$ if $\varepsilon \geq 0$ or $\rho_{\phi(e)}=(\phi-1) e$ if $\varepsilon$

$<0$.

It should be noted that the median estimator of $\phi=0.5$ is a special case of the quantile regression method. The method is most usefully thought of as providing a parsimonious way of describing the wage distribution and as such it has the potential to add significantly to any empirical analysis should the relationship between the regressors and the exogenous variables evolve across the conditional wage distribution. We also again control for sample selection within this framework, we follow Buchinsky (2001) by implementing a two stage approach, whereby step one involves estimating a selection models for both established and new immigrants using a semi-nonparametric estimator ${ }^{10}$ and, in step 2, we augment the quantile regressions with level and squared terms of the inverse mills ratios derived from step 1.

From a practical perspective, to ensure that models of this nature are correctly identified, equation 1 (the selection equation) must contain at least one variable that is absent from equation 2 (the quantile regressions) and the selected instruments should have some theoretical foundation (Himler, 2001). In the selection model we include controls for time spent abroad and cohabitation status while studying, as clearly these will tend to vary more for immigrants and will be unrelated to earnings. Generally our selected identification instruments perform well.

Table 7 presents the results from our wage equations for various quantiles of the wage distribution. The hypothesis that the costs of mismatch are lower for native graduates is tested using interactions between the two key immigrant dummies and the mismatch terms, which can then be compared to the mismatch level terms in the model. Given our earlier results, we favour the specification that distinguishes immigrants in terms of their length of stay within the host country. The wage models are well specified and generally conform to expectations. Ignoring distributional aspects of the results for now, we found that males have higher earnings than females and earnings increase with labour market experience and years in higher education. Earnings were found to increase with hours worked and were higher for those graduating from prestigious courses, engineering degrees and individuals employed in larger firms. Earnings declined with a previous history of unemployment and public sector employment. With respect to the mismatch variables, the results are in line with those reported by McGuinness and Sloane (2009), with an overeducation pay penalty in

10 The models are fitting through the semi-nonparametric estimators of Galland \& Nychka (1987) using the snp procedure in Stata. 
current employment of over 20 per cent, while overskilling is associated with a lower wage cost of approximately 4 to 5 per cent. Crucially, we found that newly arrived immigrant graduates incurred a pay penalty, while those domiciled in the host country at aged 16 earned a premium relative to native graduates. With regard to the interaction terms, we found that more newly arrived immigrants who were overskilled incurred a wage disadvantage within the low and median ranges of the wage $\backslash$ human capital distribution, however, no differential aspects were observed with regard to either immigrants with longer domicile or overeducation The selection terms indicate that newly arrived (established) immigrants, a priori, have lower (higher) than expected average earnings by virtue of their observable human capital characteristics.

Regarding the distributional aspects of the results, and assuming that an individual's position in the wage distribution reflects their productivity potential, the model suggests that the disproportional wage penalty associated with overskilling incurred by newly arrived immigrants is restricted to those with low to median levels of human capital. Newly arrived immigrants with above average levels of human capital incur no additional penalty as a consequence of becoming mismatched. With respect to the distributional spread of the remaining covariates in the model, while most impacts are relatively stable throughout the distribution, some notable patterns are evident. For instance, the return to vocational programmes and field related employment is only significant within the lower to median portions of the wage distribution.

Disaggregating our models by gender, some substantial differences become apparent. We find that within the male distribution (Table $8^{11}$ ), the premium to established immigrants is positive and rising throughout the wage / human capital distribution, while for newly arrived immigrants it is negative only in the upper regions to the wage / human capital distributions. Within the female model, the wage penalty for newly arrived immigrants is relatively persistent throughout, while a pay premium is only evident for long-term immigrants at the very top of the wage \human capital distribution. Regarding the immigrant $\backslash$ mismatch interactions, the results indicate that newly arrived male immigrants incur a higher pay penalty from overskilling relative to natives. Within the female distribution (Table $9^{12}$ ), relative to mismatched natives, newly arrived immigrants who are overeducated (overskilled) and located at the bottom (top) of the wage \human capital distribution incur larger pay penalties.

[Insert Table 7 here]

11 For the purposes of brevity, we report only the key coefficients. Full results are available from the authors on request.

12 For the purposes of brevity, we report only the key coefficients. Full results are available from the authors on request. 
[Insert Table 8 here]

[Insert Table 9 here]

With respect to job satisfaction, respondents were asked to rate their level of satisfaction with their current work on a scale from 1 to 5 , where 1 was very dissatisfied and 5 very satisfied; we classify individuals responding 4 or 5 to this question as being job satisfied. The model specification approach is similar to that adopted for the wage equations; however, as the dependant variable is binary in nature, this rules out the use of quantile regression as a control for unobserved heterogeneity. Furthermore, the estimation of a treatment model cannot be easily accommodated with sample size restrictions again ruling out the possibility of using PSM in terms of both immigration and mismatch status. In order to account, at least to some extent, for the influences of selection we estimate an augmented regression, within which the individual predicted probability of each immigrant status is included in the model as an additional covariate (see Card \& De La Rica, 2006). In our initial specification we find job satisfaction to be positively related to studying in the area of education/humanities, undertaking a course perceived to have a good reputation among employers, that is prestigious and vocational in nature, being employed in a job related to ones field of study, employed in an R\&D intensive firm and working in the public sector. Job satisfaction was inversely related to age, years spent in higher education and having experienced a previous spell of unemployment. We found that being overeducated in current employment reduced the likelihood of job satisfaction by almost 20 per cent, with the effect considerably larger for overskilling at approximately 30 per cent. Crucially we found that immigrants were 7 per cent less likely to be job satisfied, with this effect almost exclusively driven by a 14 per cent lower probability of job satisfaction among more recent immigrants (Specification 2). When we introduce our interaction terms we do not find that mismatch status among immigrant workers exacerbates the already substantial effects of either overeducation or overskilling (Specification 3).

When we estimate the models separately by gender (specifications 4 and 5), we found no evidence of lower job satisfaction among male immigrants and, in fact, established overeducated immigrants exhibited a positive interaction effect, which more or less eliminated the level effect for overeducation, suggesting that such immigrants do not have lower job satisfaction levels relative to matched workers. It may well be that such workers are being compensating for lower earnings associated with overeducation by other positive job attributes, such as increased security and / or a greater work life balance. The situation is very different for females with those domiciled (not domiciled) in the host country at aged 16 found to have a ten (fifteen) per cent lower likelihood of being job satisfied relative to native graduates. While these effects were found not to be exacerbated by the presence of either form of mismatch, they represent important findings in their own right and certainly provide grounds for further research. 
[Insert Table 10 here]

\section{Summary and Conclusions}

This paper examines the extent to which immigrant graduates have a higher exposure to educational and skill mismatch and the degree to which the previously well documented negative impacts of mismatch on earnings and job satisfaction were heightened as a consequence of immigrant status. Contrary to previous research, we found little evidence to suggest that immigrants had a higher exposure to overeducation, however, female immigrants domiciled in the host country at age 16 where found to have a higher exposure to overskilling relative to their native counterparts. With respect to earnings, the research showed that newly arrived immigrants incurred wage penalties' which were exacerbated by higher levels of penalisation resulting from overskilling in the male labour market and overeducation in the female labour market. Established immigrants were found to enjoy a wage premia, particularly within the male labour market, with no evidence of disproportionate wage impacts arising as a consequence of mismatch. In terms of job satisfaction, while there was no evidence to suggest that the negative effects of mismatch were made worse by immigrant status, we found that female immigrants, particularly newly arrived, had a much lower likelihood of being job satisfied relative to their native counterparts. The research presented here is unique in terms of its robustness given that it is free from many of the biases usually associated with studies of immigrant workers within the labour market, in addition, the integrity of the results was also ensured with additional checks for the effects of both sample selection bias and unobserved heterogeneity. 


\section{References}

Alpin, C., Shackleton, J.R., and Walsh, S. (1998). Over and Under-Education in UK Graduate Labour Market. Studies in Higher Education, 23, 17-34.

Barrett, A., McGuinness, S., and O'Brien, M. (2008). The Immigrant Earnings Disadvantage across the Earnings and Skills Distributions: The Case of Immigrants from the EU's New Member States in Ireland. British Journal of Industrial Relations, 50(3),457-481.

Battu, H. and Sloane, P.J. (2004). Over-education and ethnic minorities in Britain. Th Manchester School, 72(4), 535-559.

Bell, B.D. (1997). The performance of immigrants in the United Kingdom: Evidence from the GHS. Economic Journal, 107, 333-345.

Blackaby, D.H., Leslie, D.G., Murphy, P.D., and O'Leary, N.C. (1998). The Ethnic Wage Gap and Employment Differentials in the 1990s: Evidence from Britain. Economics Letters, 58, 97-103.

Blackaby, D.H., Leslie, D.G., Murphy, P.D., and O'Leary, N.C. (1999). Unemployment among Britain's Ethnic Minorities. The Manchester School, 67(1), 1-20.

Blackaby, D.H., Leslie, D.G., Murphy, P.D., and O'Leary, N.C. (2002). White/ethnic minority earnings and employment differentials in Britain: Evidence from the LFS. Oxford Economic Papers, 54, 270-279.

Blackaby, D.H., Leslie, D.G., Murphy, P.D., and O'Leary, N.C. (2005). Born in Britain: how are native ethnic minorities faring in the British labour market? Economics Letters, 88(3), 370-375.

Brennan, J. (2008). Overview Report to HEFCE on the Flexible Professional in the Knowledge Society, Centre for Higher Education Research and Information (CHERI), Open University, November 2008.

Buchinsky, M. (1994). Changes in the U.S.Wage Structure 1963-1987. An Application of Quantile Regression. Econometrica, 62 (2), 405-458.

Buchinsky, M. (2001)."Quantile regression with sample selection: estimating women's return to education in the U.S." Empirical Economics, 26(1), 87-113.

Card, David, and Sara De La Rica. 2006. "Firm-Level Contracting and the Structure of Wages in Spain." Industrial and Labour Relations Review 59 (4): 573-592.

Chevalier, A. (2003). Measuring Over-Education. Economica, 70, 509-531.

Clark, K., and Lindley, J. (2005). Immigrant labour market assimilation and arrival

effects: Evidence from the Labour Force Survey. University of Sheffield, Department of Economics Sheffield Economics Research Series 200505.

Connor, H., la Valle, N.D., Tackey, N.D., and Perryman, S. (1996). Differences by degrees: ethnic minority graduates, Brighton, Institute of Employment Studies.

Dex, S. and Lindley, J.K. (2007). Labour market job matching for UK minority ethnic groups. University of Sheffield, Department of Economics, Sheffield Economics Research Paper Series 2007003.

Dolton, P., and Vignoles, A. (1997). Overeducation duration: how long did graduates in the 1980s take to get a graduate level job? Unpublished mimeo, University of Newcastle.

Dolton, P., and Vignoles, A. (2000). Incidence and effects of overeducation in the UK graduate labour market. Economics of Education Review, 19(2), 179-198.

Duncan, G.J., and Hoffman, S.D. (1981). The Incidence and Wage Effects of Overeducation. Economics of Education Review, 1(1), 75-86.

Dustmann, C., and Theodoropoulos, N. (2006). Ethnic Minority Immigrants and their Children in Britain. CREAM Discussion Paper Series CDP No 10/06. 
Gallant, R. \& Nychka, N. (1987). "Semi-nonparametric maximum likelihood estimati"n", Econometrica, 55, 363-390.

Himler, J.H. (2001). A comparison of alternative specifications of the college attendance equation with an extension to two stage selectivity-correction models. Economics of Education Review, 20,262-78.

Kucel, A. and Byrne, D. (2008). 'Are over-educated people insiders or outsiders? A case of job search methods and over-education in the UK'. ESRI Working Paper No. 258.

Lindley, J. (2009). 'The over-education of UK immigrants and minority ethnic groups: Evidence from the Labour Force Survey'. Economics of Education Review 28:80-89.

Mavromaras, K., McGuinness, S., O'Leary, N.C., Sloane, P., and Fok, Y.K. (2010). The Problem of Overskilling in Australia and Britain. Manchester School, 78(3), 219-241

Mavromaras, K., McGuinness, S. (2012). Overskilling Dynamics and Education Pathways. Economics of Education Review, 31(5), 619-638.

McGuinness, S., and Mavromaras, K., McGuinness, S., O'Leary, N., Sloane, P. \& Wie Z. (2013). "Job Mismatches and Labour Market Outcomes: Panel Evidence on University Graduates,"The Economic Record, 89(286),382-395.

Wooden, M. (2009). Overskilling, Job Insecurity and Career Mobility. Industrial Relations: A Journal of Economy and Society, 48(2), 265-286.

McGuinness, S., and Sloane, P.J. (2011). Labour Market Mismatch Among UK Graduates; An Analysis Using REFLEX Data. Economics of Education Review, 30(1), 130-145.

Messinis, G. (2008a). Overeducation and overskilling in Australia: Second generation GreekAustralians and Italian-Australians. Victoria University Centre for Strategic Economic Studies Working Paper No 37.

Messinis, G. (2008b). Overeducation and overskilling in Australia: Second Generation Australians. Victoria University Centre for Strategic Economic Studies Working Paper No. 41.

Neilson (2011). Immigrant Overeducation: Evidence from Denmark. Journal of Population Economics, 24(20), pp. 499-520.

Sicherman, (1991). Overeducation in the labour market. Journal of Labor Economics, 9(2), 101-122.

Sloane, P., Battu, H. and Seaman, P. (1999). Over-education, under-education and the British Labour Market. Applied Economics, 31(11), 1437-1454. 


\section{Tables}

Table 1: Graduate Mismatch levels in Current Employment by Country

\begin{tabular}{l|cc}
\hline & Overeducation & Overskilling \\
\hline Italy & 0.13 & 0.11 \\
Spain & 0.17 & 0.15 \\
France & 0.04 & 0.14 \\
Austria & 0.10 & 0.08 \\
Germany & 0.05 & 0.09 \\
Netherlands & 0.07 & 0.09 \\
UK & 0.14 & 0.14 \\
Finland & 0.06 & 0.07 \\
Norway & 0.03 & 0.04 \\
Portugal & 0.06 & 0.03 \\
Belgium & 0.02 & 0.08 \\
\hline
\end{tabular}


Table 2: Overeducation Probit (Marginal effects)

\begin{tabular}{|c|c|c|c|}
\hline & (1) & (2) & (3) \\
\hline VARIABLES & Spec1 & Spec1 & Spec1 \\
\hline \multirow[t]{2}{*}{ Overedjob1 } & $0.07 * * *$ & $0.07 * * *$ & $0.07 * * *$ \\
\hline & $(0.004)$ & $(0.004)$ & $(0.004)$ \\
\hline \multirow[t]{2}{*}{ Overskilljob1 } & $-0.01 * * *$ & $-0.01 * * *$ & $-0.01 * * *$ \\
\hline & $(0.003)$ & $(0.003)$ & $(0.003)$ \\
\hline \multirow[t]{2}{*}{ male } & 0.00 & 0.00 & 0.00 \\
\hline & $(0.003)$ & $(0.003)$ & $(0.003)$ \\
\hline \multirow[t]{2}{*}{ Labour exp } & $-0.00 * * *$ & $-0.00 * * *$ & $-0.00 * * *$ \\
\hline & $(0.000)$ & $(0.000)$ & $(0.000)$ \\
\hline \multirow[t]{2}{*}{ age } & $0.00 * *$ & $0.00 * *$ & $0.00 * *$ \\
\hline & $(0.000)$ & $(0.000)$ & $(0.000)$ \\
\hline \multirow[t]{2}{*}{ Years HE } & $-0.01 * * *$ & $-0.01 * * *$ & $-0.01 * * *$ \\
\hline & $(0.002)$ & $(0.002)$ & $(0.002)$ \\
\hline \multirow[t]{2}{*}{ Humanities } & -0.00 & -0.00 & -0.00 \\
\hline & $(0.004)$ & $(0.004)$ & $(0.004)$ \\
\hline \multirow[t]{2}{*}{ Social } & -0.00 & -0.00 & -0.00 \\
\hline & $(0.004)$ & (0.004) & $(0.004)$ \\
\hline \multirow[t]{2}{*}{ Science } & -0.00 & -0.00 & -0.00 \\
\hline & $(0.005)$ & (0.005) & $(0.005)$ \\
\hline \multirow[t]{2}{*}{ Engineering } & -0.00 & -0.00 & -0.00 \\
\hline & $(0.005)$ & (0.005) & (0.005) \\
\hline \multirow[t]{2}{*}{ Unemploy hist } & $0.01 * * *$ & $0.01 * * *$ & $0.01 * * *$ \\
\hline & $(0.003)$ & $(0.003)$ & $(0.003)$ \\
\hline \multirow[t]{2}{*}{ migrant } & -0.00 & & \\
\hline & $(0.007)$ & & \\
\hline \multirow[t]{2}{*}{ Estab migrant } & & 0.00 & \\
\hline & & $(0.008)$ & \\
\hline \multirow[t]{2}{*}{ New migrant } & & -0.01 & \\
\hline & & $(0.012)$ & \\
\hline \multirow[t]{2}{*}{ EU 15} & & & -0.00 \\
\hline & & & $(0.010)$ \\
\hline \multirow[t]{2}{*}{ EU other } & & & 0.03 \\
\hline & & & $(0.023)$ \\
\hline \multirow[t]{2}{*}{ High income } & & & -0.05 \\
\hline & & & $(0.030)$ \\
\hline \multirow[t]{2}{*}{ Rest of world } & & & 0.00 \\
\hline & & & $(0.010)$ \\
\hline \multirow[t]{2}{*}{ Course employer } & 0.00 & 0.00 & 0.00 \\
\hline & $(0.003)$ & $(0.003)$ & $(0.003)$ \\
\hline \multirow[t]{2}{*}{ Course prestige } & $-0.01 * * *$ & $-0.01 * * *$ & $-0.01 * * *$ \\
\hline & $(0.003)$ & $(0.003)$ & $(0.003)$ \\
\hline \multirow[t]{2}{*}{ Vocational course } & 0.00 & 0.00 & 0.00 \\
\hline & $(0.003)$ & (0.003) & $(0.003)$ \\
\hline Fieldmatchnow & $-0.09 * * *$ & $-0.09 * * *$ & $-0.09 * * *$ \\
\hline & $(0.005)$ & $(0.005)$ & $(0.005)$ \\
\hline Fieldrelatednow & $-0.08 * * *$ & $-0.08 * * *$ & $-0.08 * * *$ \\
\hline & $(0.004)$ & $(0.004)$ & $(0.004)$ \\
\hline Hours & $-0.00 * *$ & $-0.00 * *$ & $-0.00 * *$ \\
\hline & $(0.000)$ & $(0.000)$ & $(0.000)$ \\
\hline R\&D Firm & $-0.01 * * *$ & $-0.01 * * *$ & $-0.01 * * *$ \\
\hline & $(0.003)$ & $(0.003)$ & $(0.003)$ \\
\hline
\end{tabular}




\begin{tabular}{|c|c|c|c|}
\hline \multirow[t]{2}{*}{ Size 50-99 } & $-0.01 * * *$ & $-0.01 * * *$ & $-0.01 * * *$ \\
\hline & $(0.005)$ & $(0.005)$ & $(0.005)$ \\
\hline \multirow[t]{2}{*}{ Size 100-249 } & $-0.01 * *$ & $-0.01 * *$ & $-0.01 * *$ \\
\hline & $(0.005)$ & $(0.005)$ & $(0.005)$ \\
\hline \multirow[t]{2}{*}{ Size 250-999 } & -0.00 & -0.00 & -0.00 \\
\hline & $(0.004)$ & $(0.004)$ & $(0.004)$ \\
\hline \multirow[t]{2}{*}{ Size $1000+$} & $-0.01 *$ & $-0.01 *$ & $-0.01 *$ \\
\hline & $(0.003)$ & $(0.003)$ & $(0.003)$ \\
\hline \multirow[t]{2}{*}{ Public sector } & $-0.01 * * *$ & $-0.01 * * *$ & $-0.01 * * *$ \\
\hline & $(0.003)$ & $(0.003)$ & $(0.003)$ \\
\hline \multirow[t]{2}{*}{$\mathrm{N}$ of employers } & $0.00 *$ & $0.00 *$ & $0.00^{*}$ \\
\hline & $(0.000)$ & $(0.000)$ & $(0.000)$ \\
\hline \multirow[t]{2}{*}{ Supervisor } & $-0.02 * * *$ & $-0.02 * * *$ & $-0.02 * * *$ \\
\hline & $(0.003)$ & $(0.003)$ & $(0.003)$ \\
\hline \multirow[t]{2}{*}{ Italy } & $0.03 * * *$ & $0.03 * * *$ & $0.03 * * *$ \\
\hline & $(0.006)$ & $(0.006)$ & $(0.006)$ \\
\hline \multirow[t]{2}{*}{ Spain } & 0.01 & 0.01 & 0.01 \\
\hline & $(0.006)$ & $(0.006)$ & $(0.006)$ \\
\hline \multirow[t]{2}{*}{ France } & $-0.04 * * *$ & $-0.04 * * *$ & $-0.04 * * *$ \\
\hline & $(0.008)$ & $(0.008)$ & $(0.008)$ \\
\hline \multirow[t]{2}{*}{ Austria } & $0.02 * *$ & $0.02 * *$ & $0.02 * * *$ \\
\hline & $(0.007)$ & $(0.007)$ & $(0.007)$ \\
\hline \multirow[t]{2}{*}{ Netherlands } & $-0.02 * *$ & $-0.02 * *$ & $-0.02 * *$ \\
\hline & $(0.007)$ & $(0.007)$ & $(0.007)$ \\
\hline \multirow[t]{2}{*}{ UK } & $-0.02 * *$ & $-0.02 * *$ & $-0.01 * *$ \\
\hline & $(0.007)$ & $(0.007)$ & $(0.007)$ \\
\hline \multirow[t]{2}{*}{ Finland } & -0.01 & -0.01 & -0.01 \\
\hline & $(0.007)$ & $(0.007)$ & $(0.007)$ \\
\hline \multirow[t]{2}{*}{ Norway } & $-0.01 *$ & $-0.01 *$ & $-0.01 *$ \\
\hline & $(0.008)$ & $(0.008)$ & $(0.008)$ \\
\hline \multirow[t]{2}{*}{ Portugal } & $0.02 *$ & $0.02 *$ & $0.02 *$ \\
\hline & $(0.010)$ & $(0.010)$ & $(0.010)$ \\
\hline \multirow[t]{2}{*}{ Belgium } & $-0.04 * * *$ & $-0.04 * * *$ & $-0.04 * * *$ \\
\hline & $(0.010)$ & $(0.010)$ & $(0.010)$ \\
\hline \multirow[t]{2}{*}{ Constant } & 0.01 & 0.01 & 0.01 \\
\hline & $(0.016)$ & $(0.016)$ & $(0.016)$ \\
\hline Pseudo $R^{2}$ & 0.394 & 0.394 & 0.395 \\
\hline Observations & 13,342 & 13,342 & 13,342 \\
\hline
\end{tabular}


Table 3: Overeducation Probit by Gender (Marginal effects for selected variables)

\begin{tabular}{lllllll}
\hline & \multicolumn{1}{c}{$(1)$} & $(2)$ & $(3)$ & $(4)$ & $(5)$ & $(6)$ \\
VARIABLES & Male 1 & Male 2 & Male 3 & Female 1 & Female 2 & Female 3 \\
\hline Overedjob1 & $0.06^{* * *}$ & $0.06^{* * *}$ & $0.06^{* * *}$ & $0.07^{* * *}$ & $0.07^{* * *}$ & $0.07^{* * *}$ \\
& $(0.006)$ & $(0.006)$ & $(0.006)$ & $(0.005)$ & $(0.005)$ & $(0.005)$ \\
Overskilljob1 & -0.01 & -0.01 & -0.01 & $-0.01^{* *}$ & $-0.01^{* *}$ & $-0.01^{* *}$ \\
& $(0.004)$ & $(0.004)$ & $(0.004)$ & $(0.004)$ & $(0.004)$ & $(0.004)$ \\
migrant & -0.00 & & & -0.00 & & \\
& $(0.010)$ & & & $(0.008)$ & & \\
Estab migrant & & 0.00 & & & 0.00 & \\
& & $(0.012)$ & & & $(0.010)$ & \\
New migrant & & -0.01 & & & -0.01 & \\
& & $(0.018)$ & & & $(0.016)$ & \\
EU 15 & & & -0.03 & & & 0.01 \\
& & & $(0.023)$ & & & $(0.012)$ \\
EU other & & & 0.03 & & & 0.03 \\
& & & $(0.034)$ & & & $-0.030)$ \\
High income & & & -0.04 & & & $(0.046)$ \\
& & & $(0.037)$ & & & -0.01 \\
Rest of world & & & 0.01 & & & $(0.013)$ \\
& & & $(0.013)$ & & & \\
& & & & & & \\
Pseudo R & 0.393 & 0.393 & 0.395 & 0.40 & 0.40 & 0.40 \\
Observations & 5,251 & 5,251 & 5,251 & 8,091 & 8,091 & 8,091 \\
\hline
\end{tabular}


Table 4: Overskilling Probit (Marginal Effects)

\begin{tabular}{|c|c|c|c|}
\hline VARIABLES & $\begin{array}{c}(1) \\
\text { Spec1 }\end{array}$ & $\begin{array}{c}(2) \\
\text { Spec1 }\end{array}$ & $\begin{array}{c}(3) \\
\text { Spec1 }\end{array}$ \\
\hline Overedjob1 & $\begin{array}{l}-0.01 \\
(0.005)\end{array}$ & $\begin{array}{l}-0.01 \\
(0.005)\end{array}$ & $\begin{array}{l}-0.01 \\
(0.005)\end{array}$ \\
\hline Overskilljob1 & $\begin{array}{l}0.10 * * * \\
(0.005)\end{array}$ & $\begin{array}{l}0.10 * * * \\
(0.005)\end{array}$ & $\begin{array}{l}0.10 * * * \\
(0.005)\end{array}$ \\
\hline male & $\begin{array}{l}0.01 * * \\
(0.004)\end{array}$ & $\begin{array}{l}0.01 * * \\
(0.004)\end{array}$ & $\begin{array}{l}0.01^{* *} \\
(0.004)\end{array}$ \\
\hline Labour exp & $\begin{array}{l}-0.00 * * * \\
(0.000)\end{array}$ & $\begin{array}{l}-0.00 * * * \\
(0.000)\end{array}$ & $\begin{array}{l}-0.00 * * * \\
(0.000)\end{array}$ \\
\hline age & $\begin{array}{l}0.00 * * \\
(0.001)\end{array}$ & $\begin{array}{l}0.00 * * \\
(0.001)\end{array}$ & $\begin{array}{l}0.00 * * \\
(0.001)\end{array}$ \\
\hline Years HE & $\begin{array}{l}0.00 \\
(0.003)\end{array}$ & $\begin{array}{l}0.00 \\
(0.003)\end{array}$ & $\begin{array}{l}0.00 \\
(0.003)\end{array}$ \\
\hline Humanities & $\begin{array}{l}-0.01 \\
(0.007)\end{array}$ & $\begin{array}{l}-0.01 \\
(0.007)\end{array}$ & $\begin{array}{l}-0.01 \\
(0.007)\end{array}$ \\
\hline Social & $\begin{array}{l}-0.00 \\
(0.006)\end{array}$ & $\begin{array}{l}-0.00 \\
(0.006)\end{array}$ & $\begin{array}{l}-0.00 \\
(0.006)\end{array}$ \\
\hline Science & $\begin{array}{l}0.01 \\
(0.007)\end{array}$ & $\begin{array}{l}0.01 \\
(0.007)\end{array}$ & $\begin{array}{l}0.01 \\
(0.007)\end{array}$ \\
\hline Engineering & $\begin{array}{l}0.00 \\
(0.007)\end{array}$ & $\begin{array}{l}0.00 \\
(0.007)\end{array}$ & $\begin{array}{l}0.00 \\
(0.007)\end{array}$ \\
\hline Unemploy hist & $\begin{array}{l}0.01 * * * \\
(0.004)\end{array}$ & $\begin{array}{l}0.01 * * * \\
(0.004)\end{array}$ & $\begin{array}{l}0.01 * * * \\
(0.004)\end{array}$ \\
\hline migrant & $\begin{array}{l}0.03 * * * \\
(0.009)\end{array}$ & & \\
\hline Estab migrant & & $\begin{array}{l}0.03 * * * \\
(0.011)\end{array}$ & \\
\hline New migrant & & $\begin{array}{l}0.02 \\
(0.017)\end{array}$ & \\
\hline EU 15 & & & $\begin{array}{l}0.03^{* *} \\
(0.014)\end{array}$ \\
\hline EU other & & & $\begin{array}{l}0.01 \\
(0.042)\end{array}$ \\
\hline High income & & & $\begin{array}{l}0.03 \\
(0.029)\end{array}$ \\
\hline Rest of world & & & $\begin{array}{l}0.02 * \\
(0.014)\end{array}$ \\
\hline Course employer & $\begin{array}{l}-0.01 * * \\
(0.004)\end{array}$ & $\begin{array}{l}-0.01 * * \\
(0.004)\end{array}$ & $\begin{array}{l}-0.01 * * \\
(0.004)\end{array}$ \\
\hline Course prestige & $\begin{array}{l}-0.02 * * * \\
(0.004)\end{array}$ & $\begin{array}{l}-0.02 * * * \\
(0.004)\end{array}$ & $\begin{array}{l}-0.02 * * * \\
(0.004)\end{array}$ \\
\hline Vocational course & $\begin{array}{l}-0.00 \\
(0.004)\end{array}$ & $\begin{array}{l}-0.00 \\
(0.004)\end{array}$ & $\begin{array}{l}-0.00 \\
(0.004)\end{array}$ \\
\hline Fieldmatchnow & $\begin{array}{l}-0.14^{* * *} \\
(0.006)\end{array}$ & $\begin{array}{l}-0.14^{* * *} \\
(0.006)\end{array}$ & $\begin{array}{l}-0.14^{* * *} \\
(0.006)\end{array}$ \\
\hline Fieldrelatednow & $\begin{array}{l}-0.10^{* * *} \\
(0.005)\end{array}$ & $\begin{array}{l}-0.10 * * * \\
(0.005)\end{array}$ & $\begin{array}{l}-0.10 * * * \\
(0.005)\end{array}$ \\
\hline Hours & $\begin{array}{l}-0.00 * \\
(0.000)\end{array}$ & $\begin{array}{l}-0.00 * \\
(0.000)\end{array}$ & $\begin{array}{l}-0.00 * \\
(0.000)\end{array}$ \\
\hline R\&D Firm & $\begin{array}{l}-0.01 * * * \\
(0.004)\end{array}$ & $\begin{array}{l}-0.01 * * * \\
(0.004)\end{array}$ & $\begin{array}{l}-0.01 * * * \\
(0.004)\end{array}$ \\
\hline
\end{tabular}




\begin{tabular}{|c|c|c|c|}
\hline Size 50-99 & $\begin{array}{l}-0.02 * * \\
(0.008)\end{array}$ & $\begin{array}{l}-0.02 * * \\
(0.008)\end{array}$ & $\begin{array}{l}-0.02 * * \\
(0.008)\end{array}$ \\
\hline Size 100-249 & $\begin{array}{l}0.01 \\
(0.007)\end{array}$ & $\begin{array}{l}0.01 \\
(0.007)\end{array}$ & $\begin{array}{l}0.01 \\
(0.007)\end{array}$ \\
\hline Size 250-999 & $\begin{array}{l}0.01 \\
(0.006)\end{array}$ & $\begin{array}{l}0.01 \\
(0.006)\end{array}$ & $\begin{array}{l}0.01 \\
(0.006)\end{array}$ \\
\hline Size $1000+$ & $\begin{array}{l}0.00 \\
(0.005)\end{array}$ & $\begin{array}{l}0.00 \\
(0.005)\end{array}$ & $\begin{array}{l}0.00 \\
(0.005)\end{array}$ \\
\hline Public sector & $\begin{array}{l}-0.02 * * * \\
(0.004)\end{array}$ & $\begin{array}{l}-0.02 * * * \\
(0.004)\end{array}$ & $\begin{array}{l}-0.02 * * * \\
(0.004)\end{array}$ \\
\hline $\mathrm{N}$ of employers & $\begin{array}{l}0.00 * \\
(0.001)\end{array}$ & $\begin{array}{l}0.00 * \\
(0.001)\end{array}$ & $\begin{array}{l}0.00 * \\
(0.001)\end{array}$ \\
\hline Supervisor & $\begin{array}{l}-0.03 * * * \\
(0.004)\end{array}$ & $\begin{array}{l}-0.03 * * * \\
(0.004)\end{array}$ & $\begin{array}{l}-0.03 * * * \\
(0.004)\end{array}$ \\
\hline Italy & $\begin{array}{l}0.00 \\
(0.009)\end{array}$ & $\begin{array}{l}0.00 \\
(0.009)\end{array}$ & $\begin{array}{l}0.00 \\
(0.009)\end{array}$ \\
\hline Spain & $\begin{array}{l}0.00 \\
(0.009)\end{array}$ & $\begin{array}{l}0.00 \\
(0.009)\end{array}$ & $\begin{array}{l}0.00 \\
(0.009)\end{array}$ \\
\hline France & $\begin{array}{l}-0.00 \\
(0.010)\end{array}$ & $\begin{array}{l}-0.00 \\
(0.010)\end{array}$ & $\begin{array}{l}-0.00 \\
(0.010)\end{array}$ \\
\hline Austria & $\begin{array}{l}-0.01 \\
(0.011)\end{array}$ & $\begin{array}{l}-0.01 \\
(0.011)\end{array}$ & $\begin{array}{l}-0.01 \\
(0.011)\end{array}$ \\
\hline Netherlands & $\begin{array}{l}-0.01 \\
(0.009)\end{array}$ & $\begin{array}{l}-0.01 \\
(0.009)\end{array}$ & $\begin{array}{l}-0.01 \\
(0.009)\end{array}$ \\
\hline UK & $\begin{array}{l}-0.01 \\
(0.011)\end{array}$ & $\begin{array}{l}-0.01 \\
(0.011)\end{array}$ & $\begin{array}{l}-0.01 \\
(0.011)\end{array}$ \\
\hline Finland & $\begin{array}{l}-0.02 \\
(0.010)\end{array}$ & $\begin{array}{l}-0.02 \\
(0.010)\end{array}$ & $\begin{array}{l}-0.02 \\
(0.010)\end{array}$ \\
\hline Norway & $\begin{array}{l}-0.01 \\
(0.010)\end{array}$ & $\begin{array}{l}-0.01 \\
(0.010)\end{array}$ & $\begin{array}{l}-0.01 \\
(0.010)\end{array}$ \\
\hline Portugal & $\begin{array}{l}-0.02 \\
(0.019)\end{array}$ & $\begin{array}{l}-0.02 \\
(0.019)\end{array}$ & $\begin{array}{l}-0.02 \\
(0.019)\end{array}$ \\
\hline Belgium & $\begin{array}{l}-0.01 \\
(0.011)\end{array}$ & $\begin{array}{l}-0.01 \\
(0.011)\end{array}$ & $\begin{array}{l}-0.01 \\
(0.011)\end{array}$ \\
\hline Constant & $\begin{array}{l}-0.06 * * \\
(0.025)\end{array}$ & $\begin{array}{l}-0.06 * * \\
(0.025)\end{array}$ & $\begin{array}{l}-0.06 * * \\
(0.025)\end{array}$ \\
\hline Pseudo $\mathrm{R}^{2}$ & 0.27 & 0.27 & 0.27 \\
\hline Observations & 13,342 & 13,342 & 13,342 \\
\hline
\end{tabular}


Table 5: Overskilling by Gender (Marginal effects for selected variables)

\begin{tabular}{|c|c|c|c|c|c|c|}
\hline VARIABLES & $\begin{array}{c}1) \\
\text { Male } 1 \\
\end{array}$ & $\begin{array}{c}(2) \\
\text { Male } 2 \\
\end{array}$ & $\begin{array}{c}3) \\
\text { Male } 3 \\
\end{array}$ & $\begin{array}{c}(4) \\
\text { Female } 1 \\
\end{array}$ & $\begin{array}{c}5) \\
\text { Female } 2 \\
\end{array}$ & $\begin{array}{c}6) \\
\text { Female } 3 \\
\end{array}$ \\
\hline Overedjob1 & $\begin{array}{l}-0.00 \\
(0.009)\end{array}$ & $\begin{array}{l}-0.00 \\
(0.009)\end{array}$ & $\begin{array}{l}-0.00 \\
(0.009)\end{array}$ & $\begin{array}{l}-0.01 \\
(0.006)\end{array}$ & $\begin{array}{l}-0.01 \\
(0.006)\end{array}$ & $\begin{array}{l}-0.01 \\
(0.006)\end{array}$ \\
\hline Overskilljob1 & $\begin{array}{l}0.11^{* * *} \\
(0.008)\end{array}$ & $\begin{array}{l}0.11^{* * *} \\
(0.008)\end{array}$ & $\begin{array}{l}0.11 * * * \\
(0.008)\end{array}$ & $\begin{array}{l}0.09 * * * \\
(0.006)\end{array}$ & $\begin{array}{l}0.09 * * * \\
(0.006)\end{array}$ & $\begin{array}{l}0.09 * * * \\
(0.006)\end{array}$ \\
\hline migrant & $\begin{array}{l}0.00 \\
(0.018)\end{array}$ & & & $\begin{array}{l}0.04 * * * \\
(0.011)\end{array}$ & & \\
\hline Estab migrant & & $\begin{array}{l}0.02 \\
(0.021)\end{array}$ & & & $\begin{array}{l}0.04 * * * \\
(0.013)\end{array}$ & \\
\hline New migrant & & $\begin{array}{l}-0.03 \\
(0.031)\end{array}$ & & & $\begin{array}{l}0.04^{* *} \\
(0.019)\end{array}$ & \\
\hline EU 15 & & & $\begin{array}{l}0.02 \\
(0.026)\end{array}$ & & & $\begin{array}{l}0.03 * * \\
(0.016)\end{array}$ \\
\hline High income & & & $\begin{array}{l}0.01 \\
(0.048)\end{array}$ & & & $\begin{array}{l}0.05 \\
(0.035)\end{array}$ \\
\hline Rest of world & & & $\begin{array}{l}-0.01 \\
(0.027)\end{array}$ & & & $\begin{array}{l}0.04^{* *} \\
(0.016)\end{array}$ \\
\hline EU other & & & & & & $\begin{array}{l}0.04 \\
(0.044)\end{array}$ \\
\hline Pseudo $\mathrm{R}^{2}$ & 0.259 & 0.259 & 0.259 & 0.282 & 0.283 & 0.283 \\
\hline Observations & 5,251 & 5,251 & 5,240 & 8,091 & 8,091 & 8,091 \\
\hline
\end{tabular}


Table 6: Results of Propensity Score Models

\begin{tabular}{lcc}
\hline & $\begin{array}{c}\text { Overeducated } \\
\text { Current Job }\end{array}$ & $\begin{array}{c}\text { Overskilled } \\
\text { Current Job }\end{array}$ \\
All Immigrant Workers & -0.02 & $0.044^{* *}$ \\
& $(0.02)$ & $(0.021)$ \\
Immigrant Males & 0.000 & 0.042 \\
& $(0.029)$ & $(0.032)$ \\
Immigrant Females & -0.007 & $0.045^{*}$ \\
& $(0.025)$ & $(0.027)$ \\
& & \\
\hline
\end{tabular}

T-Statistics in parentheses 
Table 7: Quantile Wage Equations: All Employees

\begin{tabular}{|c|c|c|c|c|c|}
\hline VARIABLES & $\begin{array}{c}\text { (1) } \\
Q .2\end{array}$ & $\begin{array}{c}\text { (2) } \\
Q .4\end{array}$ & $\begin{array}{l}\text { (3) } \\
0.5\end{array}$ & $\begin{array}{l}(4) \\
0.7\end{array}$ & $\begin{array}{l}(5) \\
0.9\end{array}$ \\
\hline \multirow[t]{2}{*}{ Overedjob1 } & $-0.02 *$ & $-0.05 * * *$ & $-0.06 * * *$ & $-0.07 * * *$ & $-0.08 * * *$ \\
\hline & $(0.013)$ & $(0.010)$ & $(0.010)$ & $(0.011)$ & $(0.014)$ \\
\hline \multirow[t]{2}{*}{ Overskilljob1 } & -0.00 & 0.01 & 0.00 & -0.01 & -0.00 \\
\hline & $(0.012)$ & $(0.010)$ & $(0.009)$ & $(0.010)$ & $(0.013)$ \\
\hline \multirow[t]{2}{*}{ Overed now } & $-0.26 * * *$ & $-0.27 * * *$ & $-0.26 * * *$ & $-0.22 * * *$ & $-0.20 * * *$ \\
\hline & $(0.018)$ & $(0.014)$ & $(0.014)$ & $(0.015)$ & (0.019) \\
\hline \multirow[t]{2}{*}{ Overskilled now } & $-0.05 * * *$ & $-0.05 * * *$ & $-0.04 * * *$ & $-0.05 * * *$ & $-0.04 * *$ \\
\hline & $(0.016)$ & $(0.013)$ & $(0.012)$ & $(0.014)$ & $(0.017)$ \\
\hline \multirow[t]{2}{*}{ Overed*estab mig } & 0.11 & 0.06 & $0.13^{*}$ & 0.12 & -0.02 \\
\hline & $(0.096)$ & $(0.076)$ & $(0.074)$ & $(0.082)$ & $(0.104)$ \\
\hline \multirow{2}{*}{ Oversk*estab mig } & 0.01 & 0.01 & -0.06 & -0.06 & -0.08 \\
\hline & $(0.080)$ & $(0.064)$ & $(0.062)$ & $(0.069)$ & $(0.088)$ \\
\hline \multirow[t]{2}{*}{ Overed*new mig } & 0.18 & 0.08 & -0.03 & $-0.24^{*}$ & -0.05 \\
\hline & $(0.165)$ & $(0.132)$ & $(0.127)$ & $(0.142)$ & $(0.181)$ \\
\hline \multirow[t]{2}{*}{ Oversk*new mig } & $-0.38 * * *$ & $-0.44 * * *$ & $-0.38 * * *$ & -0.16 & -0.12 \\
\hline & $(0.132)$ & $(0.105)$ & $(0.101)$ & $(0.113)$ & $(0.144)$ \\
\hline \multirow[t]{2}{*}{ male } & $0.09 * * *$ & $0.10 * * *$ & $0.10 * * *$ & $0.10 * * *$ & $0.13^{* * *}$ \\
\hline & (0.009) & $(0.007)$ & $(0.007)$ & $(0.008)$ & $(0.010)$ \\
\hline \multirow[t]{2}{*}{ Labour exp } & $0.00 * * *$ & $0.00 * * *$ & $0.00 * * *$ & $0.00 * * *$ & $0.00 * * *$ \\
\hline & $(0.000)$ & $(0.000)$ & $(0.000)$ & $(0.000)$ & $(0.000)$ \\
\hline \multirow[t]{2}{*}{ age } & 0.00 & -0.00 & -0.00 & -0.00 & $-0.00 * *$ \\
\hline & $(0.002)$ & $(0.001)$ & $(0.001)$ & $(0.001)$ & $(0.002)$ \\
\hline \multirow[t]{2}{*}{ Years HE } & $0.05^{* * *}$ & $0.06 * * *$ & $0.06 * * *$ & $0.07 * * *$ & $0.09 * * *$ \\
\hline & $(0.006)$ & $(0.004)$ & $(0.004)$ & $(0.005)$ & $(0.006)$ \\
\hline \multirow[t]{2}{*}{ Humanities } & 0.01 & 0.02 & 0.02 & 0.01 & 0.01 \\
\hline & $(0.013)$ & $(0.010)$ & $(0.010)$ & $(0.011)$ & $(0.014)$ \\
\hline \multirow[t]{2}{*}{ Social } & $0.06 * * *$ & $0.07 * * *$ & $0.08 * * *$ & $0.08 * * *$ & $0.10 * * *$ \\
\hline & $(0.012)$ & $(0.010)$ & (0.009) & (0.010) & (0.013) \\
\hline \multirow[t]{2}{*}{ Science } & $0.06 * * *$ & $0.07 * * *$ & $0.07 * * *$ & $0.06 * * *$ & $0.03^{*}$ \\
\hline & $(0.016)$ & $(0.012)$ & $(0.012)$ & $(0.013)$ & $(0.017)$ \\
\hline \multirow[t]{2}{*}{ Engineering } & $0.13^{* * *}$ & $0.12 * * *$ & $0.13 * * *$ & $0.11 * * *$ & $0.12 * * *$ \\
\hline & $(0.015)$ & $(0.012)$ & $(0.012)$ & $(0.013)$ & $(0.017)$ \\
\hline \multirow[t]{2}{*}{ Unemploy hist } & $-0.04 * * *$ & $-0.07 * * *$ & $-0.07 * * *$ & $-0.07 * * *$ & $-0.09 * * *$ \\
\hline & (0.009) & $(0.007)$ & $(0.007)$ & $(0.008)$ & $(0.010)$ \\
\hline \multirow[t]{2}{*}{ Estab migrant } & 0.39 & $0.44^{* *}$ & $0.65 * * *$ & $0.95^{* * *}$ & $1.32 * * *$ \\
\hline & $(0.268)$ & $(0.214)$ & $(0.207)$ & $(0.231)$ & $(0.293)$ \\
\hline \multirow[t]{2}{*}{ New migrant } & -0.30 & $-1.11 * * *$ & $-1.33^{* * *}$ & $-1.86 * * *$ & $-2.01 * * *$ \\
\hline & $(0.465)$ & $(0.371)$ & $(0.358)$ & $(0.400)$ & $(0.508)$ \\
\hline \multirow[t]{2}{*}{ Course employer } & $0.03 * * *$ & $0.02 * * *$ & $0.02 * * *$ & $0.02 * * *$ & $0.03 * * *$ \\
\hline & $(0.009)$ & $(0.007)$ & (0.007) & (0.008) & $(0.010)$ \\
\hline \multirow[t]{2}{*}{ Course prestige } & $0.03 * * *$ & $0.03 * * *$ & $0.03 * * *$ & $0.03 * * *$ & $0.03 * *$ \\
\hline & $(0.010)$ & $(0.008)$ & $(0.007)$ & $(0.008)$ & $(0.010)$ \\
\hline Vocational course & $0.03 * * *$ & $0.02 * *$ & $0.02 * *$ & 0.01 & 0.01 \\
\hline & $(0.009)$ & $(0.007)$ & $(0.007)$ & $(0.008)$ & $(0.010)$ \\
\hline Fieldmatchnow & -0.01 & 0.01 & 0.02 & 0.02 & 0.00 \\
\hline & $(0.015)$ & $(0.012)$ & $(0.011)$ & $(0.012)$ & $(0.016)$ \\
\hline Fieldrelatednow & 0.02 & $0.03 * * *$ & $0.03 * * *$ & $0.02 *$ & -0.00 \\
\hline & $(0.013)$ & $(0.010)$ & $(0.010)$ & $(0.011)$ & $(0.014)$ \\
\hline Hours & $0.02 * * *$ & $0.02 * * *$ & $0.02 * * *$ & $0.01 * * *$ & $0.01 * * *$ \\
\hline & $(0.001)$ & $(0.000)$ & $(0.000)$ & $(0.000)$ & $(0.001)$ \\
\hline
\end{tabular}




\begin{tabular}{|c|c|c|c|c|c|}
\hline R\&D Firm & $\begin{array}{l}0.01 \\
(0.008)\end{array}$ & $\begin{array}{l}0.01 * * \\
(0.007)\end{array}$ & $\begin{array}{l}0.01 * * \\
(0.006)\end{array}$ & $\begin{array}{l}0.02 * * \\
(0.007)\end{array}$ & $\begin{array}{l}0.02 * * * \\
(0.009)\end{array}$ \\
\hline \multirow[t]{2}{*}{ Size 50-99 } & $0.09 * * *$ & $0.06 * * *$ & $0.05^{* * *}$ & $0.04 * * *$ & 0.02 \\
\hline & $(0.016)$ & $(0.013)$ & $(0.012)$ & $(0.014)$ & $(0.017)$ \\
\hline \multirow[t]{2}{*}{ Size 100-249 } & $0.08 * * *$ & $0.06 * * *$ & $0.05^{* * *}$ & $0.04 * * *$ & $0.04 * * *$ \\
\hline & $(0.014)$ & $(0.011)$ & $(0.011)$ & $(0.012)$ & $(0.016)$ \\
\hline \multirow[t]{2}{*}{ Size 250-999 } & $0.08 * * *$ & $0.07 * * *$ & $0.07 * * *$ & $0.06 * * *$ & $0.08 * * *$ \\
\hline & $(0.013)$ & $(0.010)$ & $(0.010)$ & $(0.011)$ & $(0.014)$ \\
\hline \multirow[t]{2}{*}{ Size $1000+$} & $0.14 * * *$ & $0.13^{* * *}$ & $0.12 * * *$ & $0.11 * * *$ & $0.12 * * *$ \\
\hline & $(0.010)$ & $(0.008)$ & $(0.008)$ & $(0.009)$ & $(0.011)$ \\
\hline \multirow[t]{2}{*}{ Public sector } & $-0.06 * * *$ & $-0.05 * * *$ & $-0.04 * * *$ & $-0.04 * * *$ & $-0.04 * * *$ \\
\hline & (0.009) & $(0.007)$ & $(0.007)$ & $(0.008)$ & $(0.010)$ \\
\hline \multirow[t]{2}{*}{$\mathrm{N}$ of employers } & $-0.01 * * *$ & $-0.00 * *$ & $-0.00 * * *$ & -0.00 & -0.00 \\
\hline & $(0.002)$ & $(0.002)$ & $(0.002)$ & $(0.002)$ & $(0.002)$ \\
\hline \multirow[t]{2}{*}{ Supervisor } & $0.06 * * *$ & $0.06 * * *$ & $0.06 * * *$ & $0.07 * * *$ & $0.08 * * *$ \\
\hline & $(0.009)$ & $(0.007)$ & $(0.007)$ & $(0.008)$ & $(0.010)$ \\
\hline \multirow[t]{2}{*}{ Italy } & $-0.70 * * *$ & $-0.65 * * *$ & $-0.63 * * *$ & $-0.59 * * *$ & $-0.51 * * *$ \\
\hline & $(0.021)$ & $(0.017)$ & $(0.016)$ & $(0.018)$ & $(0.023)$ \\
\hline \multirow[t]{2}{*}{ Spain } & $-0.76 * * *$ & $-0.71 * * *$ & $-0.68 * * *$ & $-0.62 * * *$ & $-0.54 * * *$ \\
\hline & (0.019) & $(0.015)$ & $(0.015)$ & $(0.016)$ & $(0.021)$ \\
\hline \multirow[t]{2}{*}{ France } & $-0.31 * * *$ & $-0.30 * * *$ & $-0.29 * * *$ & $-0.28 * * *$ & $-0.30 * * *$ \\
\hline & $(0.022)$ & $(0.018)$ & $(0.017)$ & $(0.019)$ & $(0.024)$ \\
\hline \multirow[t]{2}{*}{ Austria } & $-0.26 * * *$ & $-0.26 * * *$ & $-0.26 * * *$ & $-0.25 * * *$ & $-0.20 * * *$ \\
\hline & $(0.022)$ & $(0.018)$ & $(0.017)$ & (0.019) & $(0.024)$ \\
\hline \multirow[t]{2}{*}{ Netherlands } & $-0.13 * * *$ & $-0.14 * * *$ & $-0.16 * * *$ & $-0.17 * * *$ & $-0.21 * * *$ \\
\hline & (0.019) & $(0.015)$ & $(0.015)$ & $(0.017)$ & $(0.021)$ \\
\hline \multirow[t]{2}{*}{ UK } & $-0.17 * * *$ & $-0.12 * * *$ & $-0.09 * * *$ & -0.02 & $0.07 * * *$ \\
\hline & $(0.023)$ & (0.019) & $(0.018)$ & $(0.020)$ & $(0.026)$ \\
\hline \multirow[t]{2}{*}{ Finland } & $-0.15 * * *$ & $-0.19 * * *$ & $-0.19 * * *$ & $-0.20 * * *$ & $-0.23 * * *$ \\
\hline & $(0.020)$ & $(0.016)$ & $(0.015)$ & $(0.017)$ & $(0.022)$ \\
\hline \multirow[t]{2}{*}{ Norway } & $0.14 * * *$ & $0.10 * * *$ & $0.09 * * *$ & $0.07 * * *$ & $0.08 * * *$ \\
\hline & $(0.020)$ & $(0.016)$ & $(0.015)$ & (0.017) & $(0.021)$ \\
\hline \multirow[t]{2}{*}{ Portugal } & $-0.93 * * *$ & $-0.91 * * *$ & $-0.87 * * *$ & $-0.83 * * *$ & $-0.77 * * *$ \\
\hline & $(0.031)$ & $(0.025)$ & $(0.024)$ & $(0.027)$ & $(0.034)$ \\
\hline \multirow[t]{2}{*}{ Belgium } & $-0.16 * * *$ & $-0.16 * * *$ & $-0.17 * * *$ & $-0.19 * * *$ & $-0.21 * * *$ \\
\hline & $(0.023)$ & $(0.018)$ & $(0.018)$ & $(0.020)$ & $(0.025)$ \\
\hline \multirow[t]{2}{*}{ oldmills } & -0.11 & 0.01 & -0.13 & $-0.35^{*}$ & -0.21 \\
\hline & $(0.220)$ & $(0.175)$ & (0.169) & (0.189) & $(0.240)$ \\
\hline \multirow[t]{2}{*}{ oldmills2 } & $0.24 *$ & $0.43^{* * *}$ & $0.42 * * *$ & $0.41 * * *$ & $0.88^{* * *}$ \\
\hline & (0.135) & $(0.108)$ & $(0.104)$ & $(0.116)$ & $(0.148)$ \\
\hline \multirow[t]{2}{*}{ newmills } & $-0.70 *$ & 0.12 & 0.33 & $0.77^{* *}$ & 0.48 \\
\hline & $(0.400)$ & (0.319) & $(0.308)$ & $(0.344)$ & $(0.436)$ \\
\hline \multirow[t]{2}{*}{ newmills2 } & $-0.95 * * *$ & $-0.80 * * *$ & $-0.79 * * *$ & $-0.80 * * *$ & $-1.32 * * *$ \\
\hline & $(0.316)$ & $(0.252)$ & $(0.243)$ & $(0.272)$ & $(0.345)$ \\
\hline \multirow[t]{2}{*}{ Constant } & $6.30 * * *$ & $7.25 * * *$ & $7.45^{* * *}$ & $8.01 * * *$ & $8.19 * * *$ \\
\hline & $(0.435)$ & $(0.347)$ & $(0.335)$ & $(0.374)$ & $(0.475)$ \\
\hline Pseudo $\mathrm{R}^{2}$ & 0.407 & 0.394 & 0.381 & 0.340 & 0.278 \\
\hline Observations & 12,622 & 12,622 & 12,622 & 12,622 & 12,622 \\
\hline
\end{tabular}


Table 8: Quantile Wage Equations (selected coefficients): Males

\begin{tabular}{|c|c|c|c|c|c|}
\hline YARIARIES & (1) & (2) & (3) & (4) & (5) \\
\hline VAKIABLES & & & & & \\
\hline Overedjob1 & $\begin{array}{l}-0.06 * * * \\
(0.020)\end{array}$ & $\begin{array}{l}-0.08^{* * *} \\
(0.018)\end{array}$ & $\begin{array}{l}-0.05 * * * \\
(0.016)\end{array}$ & $\begin{array}{l}-0.08 * * * \\
(0.019)\end{array}$ & $\begin{array}{l}-0.09 * * * \\
(0.024)\end{array}$ \\
\hline Overskilljob1 & $\begin{array}{l}-0.00 \\
(0.017)\end{array}$ & $\begin{array}{l}0.00 \\
(0.015)\end{array}$ & $\begin{array}{l}-0.00 \\
(0.014)\end{array}$ & $\begin{array}{l}-0.02 \\
(0.016)\end{array}$ & $\begin{array}{l}-0.02 \\
(0.021)\end{array}$ \\
\hline Overed now & $\begin{array}{l}-0.26 * * * \\
(0.028)\end{array}$ & $\begin{array}{l}-0.24^{* * *} \\
(0.024)\end{array}$ & $\begin{array}{l}-0.23 * * * \\
(0.022)\end{array}$ & $\begin{array}{l}-0.18^{* * *} \\
(0.026)\end{array}$ & $\begin{array}{l}-0.20 * * * \\
(0.033)\end{array}$ \\
\hline Overskilled now & $\begin{array}{l}-0.02 \\
(0.023)\end{array}$ & $\begin{array}{l}-0.05 * * \\
(0.020)\end{array}$ & $\begin{array}{l}-0.02 \\
(0.018)\end{array}$ & $\begin{array}{l}-0.03 \\
(0.021)\end{array}$ & $\begin{array}{l}-0.02 \\
(0.027)\end{array}$ \\
\hline Overed*estab mig & $\begin{array}{l}0.04 \\
(0.164)\end{array}$ & $\begin{array}{l}-0.11 \\
(0.142)\end{array}$ & $\begin{array}{l}-0.10 \\
(0.128)\end{array}$ & $\begin{array}{l}0.03 \\
(0.154)\end{array}$ & $\begin{array}{l}0.28 \\
(0.196)\end{array}$ \\
\hline Oversk*estab mig & $\begin{array}{l}0.03 \\
(0.134)\end{array}$ & $\begin{array}{l}-0.09 \\
(0.116)\end{array}$ & $\begin{array}{l}-0.13 \\
(0.104)\end{array}$ & $\begin{array}{l}-0.11 \\
(0.126)\end{array}$ & $\begin{array}{l}-0.43 * * * \\
(0.160)\end{array}$ \\
\hline Overed*new mig & $\begin{array}{l}0.04 \\
(0.218)\end{array}$ & $\begin{array}{l}-0.00 \\
(0.189)\end{array}$ & $\begin{array}{l}-0.17 \\
(0.170)\end{array}$ & $\begin{array}{l}0.08 \\
(0.205)\end{array}$ & $\begin{array}{l}-0.08 \\
(0.260)\end{array}$ \\
\hline Oversk*new mig & $\begin{array}{l}-0.74 * * * \\
(0.218)\end{array}$ & $\begin{array}{l}-0.45^{* *} \\
(0.189)\end{array}$ & $\begin{array}{l}-0.53 * * * \\
(0.169)\end{array}$ & $\begin{array}{l}-0.84^{* * *} \\
(0.205)\end{array}$ & $\begin{array}{l}-0.31 \\
(0.260)\end{array}$ \\
\hline Estab migrant & $\begin{array}{l}0.66^{*} \\
(0.359)\end{array}$ & $\begin{array}{l}0.96 * * * \\
(0.311)\end{array}$ & $\begin{array}{l}0.82 * * * \\
(0.279)\end{array}$ & $\begin{array}{l}1.00 * * * \\
(0.337)\end{array}$ & $\begin{array}{l}1.31^{* * *} \\
(0.427)\end{array}$ \\
\hline New migrant & $\begin{array}{l}-0.08 \\
(0.679) \\
(0.297)\end{array}$ & $\begin{array}{l}-0.62 \\
(0.589) \\
(0.258)\end{array}$ & $\begin{array}{l}-1.13^{* *} \\
(0.528) \\
(0.231)\end{array}$ & $\begin{array}{l}-0.66 \\
(0.638) \\
(0.279)\end{array}$ & $\begin{array}{l}-1.93 * * \\
(0.809) \\
(0.354)\end{array}$ \\
\hline oldmills2 & $\begin{array}{l}0.22 \\
(0.170)\end{array}$ & $\begin{array}{l}0.28^{*} \\
(0.147)\end{array}$ & $\begin{array}{l}0.31^{* *} \\
(0.132)\end{array}$ & $\begin{array}{l}0.38 * * \\
(0.160)\end{array}$ & $\begin{array}{l}0.69 * * * \\
(0.203)\end{array}$ \\
\hline newmills & $\begin{array}{l}-1.10^{*} \\
(0.610)\end{array}$ & $\begin{array}{l}-0.50 \\
(0.529)\end{array}$ & $\begin{array}{l}0.26 \\
(0.474)\end{array}$ & $\begin{array}{l}-0.65 \\
(0.573)\end{array}$ & $\begin{array}{l}0.94 \\
(0.727)\end{array}$ \\
\hline newmills2 & $\begin{array}{l}-1.19 * * \\
(0.463)\end{array}$ & $\begin{array}{l}-1.02 * * \\
(0.401)\end{array}$ & $\begin{array}{l}-0.65^{*} \\
(0.360)\end{array}$ & $\begin{array}{l}-1.34 * * * \\
(0.435)\end{array}$ & $\begin{array}{l}-0.75 \\
(0.552)\end{array}$ \\
\hline Pseudo $\mathrm{R}^{2}$ & 0.399 & 0.381 & 0.368 & 0.334 & 0.267 \\
\hline Observations & 5,018 & 5,018 & 5,018 & 5,018 & 5,018 \\
\hline
\end{tabular}

Standard errors in parentheses

$* * * p<0.01, * * p<0.05, * p<0.1$ 
Table 9: Quantile Wage Equations (selected coefficients): Females

\begin{tabular}{|c|c|c|c|c|c|}
\hline & (1) & (2) & (3) & (4) & (5) \\
\hline VARIABLES & Q.2 & Q.4 & Q.5 & Q.7 & Q.0 \\
\hline \multirow[t]{2}{*}{ Overedjob1 } & -0.02 & $-0.05 * * *$ & $-0.05 * * *$ & $-0.08 * * *$ & $-0.08 * * *$ \\
\hline & (0.017) & $(0.013)$ & $(0.013)$ & $(0.014)$ & $(0.017)$ \\
\hline \multirow[t]{2}{*}{ Overskilljob1 } & 0.01 & 0.01 & 0.01 & -0.00 & 0.01 \\
\hline & $(0.016)$ & $(0.013)$ & $(0.013)$ & $(0.013)$ & (0.017) \\
\hline \multirow[t]{2}{*}{ Overed now } & $-0.25 * * *$ & $-0.27 * * *$ & $-0.25 * * *$ & $-0.23 * * *$ & $-0.19 * * *$ \\
\hline & $(0.023)$ & $(0.018)$ & $(0.018)$ & $(0.018)$ & $(0.024)$ \\
\hline \multirow[t]{2}{*}{ Overskilled now } & $-0.07 * * *$ & $-0.05 * * *$ & $-0.07 * * *$ & $-0.06 * * *$ & $-0.07 * * *$ \\
\hline & $(0.022)$ & $(0.017)$ & $(0.017)$ & $(0.017)$ & $(0.022)$ \\
\hline \multirow[t]{2}{*}{ Overed*estab mig } & 0.13 & 0.07 & 0.11 & 0.11 & -0.04 \\
\hline & $(0.118)$ & $(0.093)$ & $(0.093)$ & $(0.096)$ & $(0.122)$ \\
\hline \multirow[t]{2}{*}{ Oversk*estab mig } & 0.05 & 0.05 & -0.01 & -0.01 & -0.07 \\
\hline & $(0.101)$ & (0.079) & $(0.079)$ & $(0.081)$ & $(0.103)$ \\
\hline \multirow[t]{2}{*}{ Overed*new mig } & 0.21 & -0.26 & -0.26 & $-0.47 * *$ & $-0.55^{* *}$ \\
\hline & $(0.245)$ & $(0.191)$ & (0.193) & (0.197) & $(0.251)$ \\
\hline \multirow[t]{2}{*}{ Oversk*new mig } & $-0.44 * *$ & 0.01 & -0.15 & -0.01 & -0.10 \\
\hline & $(0.172)$ & $(0.135)$ & $(0.135)$ & (0.139) & $(0.176)$ \\
\hline \multirow[t]{2}{*}{ Estab migrant } & 0.18 & -0.11 & -0.02 & 0.48 & $1.30 * * *$ \\
\hline & $(0.431)$ & $(0.337)$ & $(0.340)$ & $(0.348)$ & $(0.443)$ \\
\hline \multirow[t]{2}{*}{ New migrant } & -0.61 & $-1.29 * *$ & $-1.28 * *$ & $-2.03 * * *$ & $-2.57 * * *$ \\
\hline & $(0.642)$ & $(0.502)$ & $(0.505)$ & (0.518) & $(0.658)$ \\
\hline \multirow[t]{2}{*}{ oldmills } & -0.05 & 0.43 & 0.37 & 0.01 & -0.07 \\
\hline & (0.337) & $(0.264)$ & $(0.266)$ & $(0.272)$ & $(0.346)$ \\
\hline \multirow[t]{2}{*}{ oldmills2 } & 0.15 & $0.45^{* *}$ & $0.44^{* *}$ & $0.44^{* *}$ & $1.03 * * *$ \\
\hline & $(0.235)$ & $(0.184)$ & $(0.185)$ & $(0.190)$ & $(0.241)$ \\
\hline \multirow[t]{2}{*}{ newmills } & -0.07 & 0.48 & 0.52 & $0.98 * *$ & 0.33 \\
\hline & $(0.523)$ & $(0.409)$ & $(0.412)$ & $(0.422)$ & $(0.536)$ \\
\hline \multirow[t]{2}{*}{ newmills2 } & -0.57 & $-0.60 *$ & $-0.57 *$ & $-0.70 * *$ & $-1.99 * * *$ \\
\hline & $(0.435)$ & $(0.340)$ & $(0.343)$ & $(0.351)$ & $(0.446)$ \\
\hline Pseudo $\mathrm{R}^{2}$ & 0.402 & 0.372 & 0.353 & 0.306 & 0.253 \\
\hline Observations & 7,604 & 7,604 & 7,604 & 7,604 & 7,604 \\
\hline
\end{tabular}

Standard errors in parentheses $* * * p<0.01, * * p<0.05, * p<0.1$ 
Table 10: Job Satisfaction Equation

\begin{tabular}{|c|c|c|c|c|c|}
\hline VARIABLES & $\begin{array}{c}(1) \\
\text { Spec1 } \\
\end{array}$ & $\begin{array}{c}(2) \\
\text { Spec2 } \\
\end{array}$ & $\begin{array}{c}(3) \\
\text { Spec3 } \\
\end{array}$ & $\begin{array}{c}(4) \\
\text { Male } \\
\end{array}$ & $\begin{array}{c}(5) \\
\text { Female } \\
\end{array}$ \\
\hline Overedjob1 & $\begin{array}{l}-0.00 \\
(0.014)\end{array}$ & $\begin{array}{l}-0.00 \\
(0.014)\end{array}$ & $\begin{array}{l}-0.00 \\
(0.014)\end{array}$ & $\begin{array}{l}-0.01 \\
(0.023)\end{array}$ & $\begin{array}{l}-0.00 \\
(0.017)\end{array}$ \\
\hline Overskilljob1 & $\begin{array}{l}-0.02 * \\
(0.013)\end{array}$ & $\begin{array}{l}-0.02 * \\
(0.013)\end{array}$ & $\begin{array}{l}-0.02 \\
(0.013)\end{array}$ & $\begin{array}{l}-0.02 \\
(0.020)\end{array}$ & $\begin{array}{l}-0.02 \\
(0.017)\end{array}$ \\
\hline Overed now & $\begin{array}{l}-0.17^{* * *} \\
(0.018)\end{array}$ & $\begin{array}{l}-0.17^{* * *} \\
(0.018)\end{array}$ & $\begin{array}{l}-0.18^{* * *} \\
(0.018)\end{array}$ & $\begin{array}{l}-0.18^{* * *} \\
(0.032)\end{array}$ & $\begin{array}{l}-0.18^{* * *} \\
(0.023)\end{array}$ \\
\hline Overskilled now & $\begin{array}{l}-0.28 * * * \\
(0.016)\end{array}$ & $\begin{array}{l}-0.28 * * * \\
(0.016)\end{array}$ & $\begin{array}{l}-0.28 * * * \\
(0.017)\end{array}$ & $\begin{array}{l}-0.28 * * * \\
(0.026)\end{array}$ & $\begin{array}{l}-0.27 * * * \\
(0.022)\end{array}$ \\
\hline overed*Estab migrant & & & $\begin{array}{l}0.12 \\
(0.098)\end{array}$ & $\begin{array}{l}0.31 \\
(0.193)\end{array}$ & $\begin{array}{l}0.06 \\
(0.117)\end{array}$ \\
\hline overskill*Estab migrant & & & $\begin{array}{l}-0.01 \\
(0.085)\end{array}$ & $\begin{array}{l}-0.11 \\
(0.157)\end{array}$ & $\begin{array}{l}0.03 \\
(0.101)\end{array}$ \\
\hline Overed*new migrant & & & $\begin{array}{l}0.01 \\
(0.205)\end{array}$ & $\begin{array}{l}-0.06 \\
(0.291)\end{array}$ & $\begin{array}{l}0.02 \\
(0.284)\end{array}$ \\
\hline Oversk*new migrant & & & $\begin{array}{l}-0.15 \\
(0.157)\end{array}$ & & $\begin{array}{l}-0.04 \\
(0.182)\end{array}$ \\
\hline male & $\begin{array}{l}-0.02 * \\
(0.009)\end{array}$ & $\begin{array}{l}-0.02 * \\
(0.009)\end{array}$ & $\begin{array}{l}-0.01 \\
(0.010)\end{array}$ & & \\
\hline Labour exp & $\begin{array}{l}0.00 \\
(0.000)\end{array}$ & $\begin{array}{l}0.00 \\
(0.000)\end{array}$ & $\begin{array}{l}0.00 * \\
(0.000)\end{array}$ & $\begin{array}{l}0.00 * * \\
(0.001)\end{array}$ & $\begin{array}{l}0.00 \\
(0.001)\end{array}$ \\
\hline age & $\begin{array}{l}-0.00 * * * \\
(0.001)\end{array}$ & $\begin{array}{l}-0.00 * * * \\
(0.001)\end{array}$ & $\begin{array}{l}-0.01 * * * \\
(0.002)\end{array}$ & $\begin{array}{l}-0.01 * * * \\
(0.003)\end{array}$ & $\begin{array}{l}-0.00 * \\
(0.002)\end{array}$ \\
\hline Years HE & $\begin{array}{l}-0.01 * * \\
(0.005)\end{array}$ & $\begin{array}{l}-0.01 * * \\
(0.005)\end{array}$ & $\begin{array}{l}-0.01 * * \\
(0.005)\end{array}$ & $\begin{array}{l}0.00 \\
(0.009)\end{array}$ & $\begin{array}{l}-0.02 * * * \\
(0.007)\end{array}$ \\
\hline Humanities & $\begin{array}{l}0.05^{* * *} \\
(0.014)\end{array}$ & $\begin{array}{l}0.05^{* * *} \\
(0.014)\end{array}$ & $\begin{array}{l}0.05^{* * *} \\
(0.015)\end{array}$ & $\begin{array}{l}0.05^{*} \\
(0.030)\end{array}$ & $\begin{array}{l}0.05^{* * *} \\
(0.017)\end{array}$ \\
\hline Social & $\begin{array}{l}0.00 \\
(0.013)\end{array}$ & $\begin{array}{l}0.00 \\
(0.013)\end{array}$ & $\begin{array}{l}0.01 \\
(0.013)\end{array}$ & $\begin{array}{l}0.01 \\
(0.024)\end{array}$ & $\begin{array}{l}0.01 \\
(0.016)\end{array}$ \\
\hline Science & $\begin{array}{l}0.02 \\
(0.017)\end{array}$ & $\begin{array}{l}0.02 \\
(0.017)\end{array}$ & $\begin{array}{l}0.02 \\
(0.017)\end{array}$ & $\begin{array}{l}0.03 \\
(0.027)\end{array}$ & $\begin{array}{l}0.02 \\
(0.022)\end{array}$ \\
\hline Engineering & $\begin{array}{l}-0.00 \\
(0.016)\end{array}$ & $\begin{array}{l}-0.00 \\
(0.016)\end{array}$ & $\begin{array}{l}-0.00 \\
(0.016)\end{array}$ & $\begin{array}{l}0.01 \\
(0.024)\end{array}$ & $\begin{array}{l}-0.02 \\
(0.024)\end{array}$ \\
\hline Unemploy hist & $\begin{array}{l}-0.03 * * * \\
(0.010)\end{array}$ & $\begin{array}{l}-0.03 * * * \\
(0.010)\end{array}$ & $\begin{array}{l}-0.03 * * * \\
(0.010)\end{array}$ & $\begin{array}{l}-0.03^{*} \\
(0.016)\end{array}$ & $\begin{array}{l}-0.03 * * \\
(0.013)\end{array}$ \\
\hline migrant & $\begin{array}{l}-0.07 * * * \\
(0.023)\end{array}$ & & & & \\
\hline Estab migrant & & $\begin{array}{l}-0.04 \\
(0.028)\end{array}$ & $\begin{array}{l}-0.05^{*} \\
(0.031)\end{array}$ & $\begin{array}{l}0.03 \\
(0.054)\end{array}$ & $\begin{array}{l}-0.10 * * \\
(0.039)\end{array}$ \\
\hline New migrant & & $\begin{array}{l}-0.13 * * * \\
(0.039)\end{array}$ & $\begin{array}{l}-0.12 * * * \\
(0.041)\end{array}$ & $\begin{array}{l}-0.09 \\
(0.068)\end{array}$ & $\begin{array}{l}-0.14 * * * \\
(0.051)\end{array}$ \\
\hline Course employer & $\begin{array}{l}0.04 * * * \\
(0.009)\end{array}$ & $\begin{array}{l}0.04 * * * \\
(0.009)\end{array}$ & $\begin{array}{l}0.04 * * * \\
(0.009)\end{array}$ & $\begin{array}{l}0.05^{* * *} \\
(0.015)\end{array}$ & $\begin{array}{l}0.03 * * * \\
(0.012)\end{array}$ \\
\hline Course prestige & $\begin{array}{l}0.04 * * * \\
(0.010)\end{array}$ & $\begin{array}{l}0.03 * * * \\
(0.010)\end{array}$ & $\begin{array}{l}0.03 * * * \\
(0.010)\end{array}$ & $\begin{array}{l}0.04 * * * \\
(0.016)\end{array}$ & $\begin{array}{l}0.02 \\
(0.014)\end{array}$ \\
\hline Vocational course & $\begin{array}{l}0.03 * * * \\
(0.010)\end{array}$ & $\begin{array}{l}0.03 * * * \\
(0.010)\end{array}$ & $\begin{array}{l}0.03 * * * \\
(0.010)\end{array}$ & $\begin{array}{l}0.03 * * \\
(0.015)\end{array}$ & $\begin{array}{l}0.03^{* *} \\
(0.013)\end{array}$ \\
\hline Fieldmatchnow & $\begin{array}{l}0.06 * * * \\
(0.015)\end{array}$ & $\begin{array}{l}0.06 * * * \\
(0.015)\end{array}$ & $\begin{array}{l}0.05 * * * \\
(0.015)\end{array}$ & $\begin{array}{l}0.04^{*} \\
(0.025)\end{array}$ & $\begin{array}{l}0.06 * * * \\
(0.020)\end{array}$ \\
\hline Fieldrelatednow & $\begin{array}{l}0.01 \\
(0.014)\end{array}$ & $\begin{array}{l}0.01 \\
(0.014)\end{array}$ & $\begin{array}{l}0.01 \\
(0.014)\end{array}$ & $\begin{array}{l}0.00 \\
(0.022)\end{array}$ & $\begin{array}{l}0.01 \\
(0.017)\end{array}$ \\
\hline
\end{tabular}




\begin{tabular}{|c|c|c|c|c|c|}
\hline Hours & $\begin{array}{l}0.00 \\
(0.001)\end{array}$ & $\begin{array}{l}0.00 \\
(0.001)\end{array}$ & $\begin{array}{l}0.00 \\
(0.001)\end{array}$ & $\begin{array}{l}0.00 \\
(0.001)\end{array}$ & $\begin{array}{l}0.00 \\
(0.001)\end{array}$ \\
\hline R\&D Firm & $\begin{array}{l}0.11^{* * *} \\
(0.009)\end{array}$ & $\begin{array}{l}0.11 * * * \\
(0.009)\end{array}$ & $\begin{array}{l}0.11^{* * *} \\
(0.009)\end{array}$ & $\begin{array}{l}0.13^{* * *} \\
(0.014)\end{array}$ & $\begin{array}{l}0.11 * * * \\
(0.012)\end{array}$ \\
\hline Size 50-99 & $\begin{array}{l}-0.01 \\
(0.017)\end{array}$ & $\begin{array}{l}-0.01 \\
(0.017)\end{array}$ & $\begin{array}{l}-0.01 \\
(0.017)\end{array}$ & $\begin{array}{l}0.01 \\
(0.029)\end{array}$ & $\begin{array}{l}-0.03 \\
(0.022)\end{array}$ \\
\hline Size $100-249$ & $\begin{array}{l}-0.02 \\
(0.015)\end{array}$ & $\begin{array}{l}-0.02 \\
(0.015)\end{array}$ & $\begin{array}{l}-0.02 \\
(0.016)\end{array}$ & $\begin{array}{l}-0.01 \\
(0.027)\end{array}$ & $\begin{array}{l}-0.03 \\
(0.020)\end{array}$ \\
\hline Size 250-999 & $\begin{array}{l}-0.02 * \\
(0.014)\end{array}$ & $\begin{array}{l}-0.02 * \\
(0.014)\end{array}$ & $\begin{array}{l}-0.02 * \\
(0.014)\end{array}$ & $\begin{array}{l}-0.02 \\
(0.023)\end{array}$ & $\begin{array}{l}-0.03 \\
(0.017)\end{array}$ \\
\hline Size $1000+$ & $\begin{array}{l}0.00 \\
(0.011)\end{array}$ & $\begin{array}{l}0.00 \\
(0.011)\end{array}$ & $\begin{array}{l}-0.00 \\
(0.011)\end{array}$ & $\begin{array}{l}0.00 \\
(0.018)\end{array}$ & $\begin{array}{l}-0.01 \\
(0.015)\end{array}$ \\
\hline Public sector & $\begin{array}{l}0.09 * * * \\
(0.010)\end{array}$ & $\begin{array}{l}0.09 * * * \\
(0.010)\end{array}$ & $\begin{array}{l}0.09 * * * \\
(0.010)\end{array}$ & $\begin{array}{l}0.09 * * * \\
(0.018)\end{array}$ & $\begin{array}{l}0.10^{* * *} \\
(0.013)\end{array}$ \\
\hline $\mathrm{N}$ of employers & $\begin{array}{l}0.00 \\
(0.002)\end{array}$ & $\begin{array}{l}0.00 \\
(0.002)\end{array}$ & $\begin{array}{l}-0.00 \\
(0.002)\end{array}$ & $\begin{array}{l}0.00 \\
(0.004)\end{array}$ & $\begin{array}{l}-0.00 \\
(0.003)\end{array}$ \\
\hline Supervisor & $\begin{array}{l}0.02 * * * \\
(0.009)\end{array}$ & $\begin{array}{l}0.02 * * * \\
(0.009)\end{array}$ & $\begin{array}{l}0.02 * * \\
(0.009)\end{array}$ & $\begin{array}{l}0.04^{* * *} \\
(0.015)\end{array}$ & $\begin{array}{l}0.01 \\
(0.012)\end{array}$ \\
\hline Italy & $\begin{array}{l}-0.13 * * * \\
(0.021)\end{array}$ & $\begin{array}{l}-0.13 * * * \\
(0.021)\end{array}$ & $\begin{array}{l}-0.11^{* * *} \\
(0.029)\end{array}$ & $\begin{array}{l}-0.09 * * \\
(0.043)\end{array}$ & $\begin{array}{l}-0.11 * * * \\
(0.040)\end{array}$ \\
\hline Spain & $\begin{array}{l}-0.05 * * * \\
(0.020)\end{array}$ & $\begin{array}{l}-0.05 * * * \\
(0.020)\end{array}$ & $\begin{array}{l}-0.04 \\
(0.024)\end{array}$ & $\begin{array}{l}-0.03 \\
(0.036)\end{array}$ & $\begin{array}{l}-0.04 \\
(0.033)\end{array}$ \\
\hline France & $\begin{array}{l}-0.03 \\
(0.024)\end{array}$ & $\begin{array}{l}-0.03 \\
(0.024)\end{array}$ & $\begin{array}{l}-0.02 \\
(0.025)\end{array}$ & $\begin{array}{l}-0.01 \\
(0.040)\end{array}$ & $\begin{array}{l}-0.02 \\
(0.034)\end{array}$ \\
\hline Austria & $\begin{array}{l}0.03 \\
(0.024)\end{array}$ & $\begin{array}{l}0.04 \\
(0.024)\end{array}$ & $\begin{array}{l}0.04 \\
(0.024)\end{array}$ & $\begin{array}{l}0.05 \\
(0.035)\end{array}$ & $\begin{array}{l}0.02 \\
(0.035)\end{array}$ \\
\hline Netherlands & $\begin{array}{l}-0.07 * * * \\
(0.021)\end{array}$ & $\begin{array}{l}-0.07 * * * \\
(0.021)\end{array}$ & $\begin{array}{l}-0.07 * * * \\
(0.021)\end{array}$ & $\begin{array}{l}-0.08 * * \\
(0.031)\end{array}$ & $\begin{array}{l}-0.07^{* *} \\
(0.029)\end{array}$ \\
\hline UK & $\begin{array}{l}-0.09 * * * \\
(0.025)\end{array}$ & $\begin{array}{l}-0.09 * * * \\
(0.025)\end{array}$ & $\begin{array}{l}-0.11 * * * \\
(0.037)\end{array}$ & $\begin{array}{l}-0.14^{* *} \\
(0.059)\end{array}$ & $\begin{array}{l}-0.12 * * \\
(0.048)\end{array}$ \\
\hline Finland & $\begin{array}{l}-0.11 * * * \\
(0.021)\end{array}$ & $\begin{array}{l}-0.11 * * * \\
(0.021)\end{array}$ & $\begin{array}{l}-0.09 * * * \\
(0.024)\end{array}$ & $\begin{array}{l}-0.07^{*} \\
(0.037)\end{array}$ & $\begin{array}{l}-0.10 * * * \\
(0.034)\end{array}$ \\
\hline Norway & $\begin{array}{l}-0.06 * * * \\
(0.021)\end{array}$ & $\begin{array}{l}-0.06 * * * \\
(0.021)\end{array}$ & $\begin{array}{l}-0.06 * * * \\
(0.021)\end{array}$ & $\begin{array}{l}-0.03 \\
(0.031)\end{array}$ & $\begin{array}{l}-0.08 * * * \\
(0.030)\end{array}$ \\
\hline Portugal & $\begin{array}{l}-0.16^{* * *} \\
(0.033)\end{array}$ & $\begin{array}{l}-0.16^{* * *} \\
(0.033)\end{array}$ & $\begin{array}{l}-0.15^{* * *} \\
(0.036)\end{array}$ & $\begin{array}{l}-0.14^{* *} \\
(0.059)\end{array}$ & $\begin{array}{l}-0.14 * * * \\
(0.047)\end{array}$ \\
\hline Belgium & $\begin{array}{l}-0.04 \\
(0.024)\end{array}$ & $\begin{array}{l}-0.04 \\
(0.024)\end{array}$ & $\begin{array}{l}-0.02 \\
(0.028)\end{array}$ & $\begin{array}{l}-0.03 \\
(0.041)\end{array}$ & $\begin{array}{l}-0.01 \\
(0.039)\end{array}$ \\
\hline scores & & & $\begin{array}{l}0.50 \\
(0.486)\end{array}$ & $\begin{array}{l}1.44^{*} \\
(0.824)\end{array}$ & $\begin{array}{l}0.35 \\
(0.621)\end{array}$ \\
\hline Constant & $\begin{array}{l}0.26 * * * \\
(0.057)\end{array}$ & $\begin{array}{l}0.25 * * * \\
(0.057)\end{array}$ & $\begin{array}{l}0.26 * * * \\
(0.057)\end{array}$ & $\begin{array}{l}0.20 * * \\
(0.101)\end{array}$ & $\begin{array}{l}0.28 * * * \\
(0.070)\end{array}$ \\
\hline Pseudo $\mathrm{R}^{2}$ & 0.092 & 0.092 & 0.092 & 0.095 & 0.093 \\
\hline Observations & 13,342 & 13,342 & 13,342 & 5,246 & 8,091 \\
\hline
\end{tabular}




\section{Data Appendix}

Table A1: Distribution of Immigrant Population by Country

\begin{tabular}{l|ll}
\hline Country of birth of respondent & Freq. & Percent \\
\hline Germany & 49 & 9.88 \\
France & 24 & 4.84 \\
Greece & 21 & 4.23 \\
Suriname & 21 & 4.23 \\
Sweden & 21 & 4.23 \\
Italy & 19 & 3.83 \\
united states & 19 & 3.83 \\
Ireland & 18 & 3.63 \\
Switzerland & 18 & 3.63 \\
morocco & 14 & 2.82 \\
united kingdom & 13 & 2.62 \\
Belgium & 12 & 2.42 \\
India & 11 & 2.22 \\
Poland & 11 & 2.22 \\
Venezuela & 11 & 2.22 \\
turkey & 10 & 2.02 \\
Iran & 9 & 1.81 \\
Korea, south & 9 & 1.81 \\
Denmark & 8 & 1.61 \\
Netherlands & 8 & 1.61 \\
Russia & 8 & 1.61 \\
Vietnam & 8 & 1.61 \\
Netherlands antilles & 7 & 1.41 \\
Romania & 7 & 1.41 \\
south Africa & 3 & 1.21 \\
Canada & 3 & 0.6 \\
Israel & 3 & \\
Australia & 3 & 1.01 \\
china & 5 & 1.01 \\
Hong Kong & 4 & 0.81 \\
Iceland & 4 & 0.81 \\
Spain & 4 & 0.81 \\
Bosnia and Herzegovina & 4 & 0.81 \\
Finland & 4 & 0.81 \\
Gibraltar & 3 & 0.6 \\
Hungary & 3.6 \\
Kapan & 3.6 \\
\hline & 3 \\
\hline
\end{tabular}




\begin{tabular}{|c|c|c|}
\hline Luxembourg & 3 & 0.6 \\
\hline Mauritius & 3 & 0.6 \\
\hline Tunisia & 3 & 0.6 \\
\hline Andorra & 2 & 0.4 \\
\hline Argentina & 2 & 0.4 \\
\hline Bangladesh & 2 & 0.4 \\
\hline brazil & 2 & 0.4 \\
\hline cote d ivoire & 2 & 0.4 \\
\hline Croatia & 2 & 0.4 \\
\hline Cyprus & 2 & 0.4 \\
\hline Estonia & 2 & 0.4 \\
\hline Ghana & 2 & 0.4 \\
\hline Latvia & 2 & 0.4 \\
\hline Monaco & 2 & 0.4 \\
\hline Nepal & 2 & 0.4 \\
\hline New Zealand & 2 & 0.4 \\
\hline Nigeria & 2 & 0.4 \\
\hline Philippines & 2 & 0.4 \\
\hline Portugal & 2 & 0.4 \\
\hline Singapore & 2 & 0.4 \\
\hline Slovakia & 2 & 0.4 \\
\hline Ukraine & 2 & 0.4 \\
\hline united Arab emirates & 2 & 0.4 \\
\hline Zambia & 2 & 0.4 \\
\hline Afghanistan & 1 & 0.2 \\
\hline Aruba & 1 & 0.2 \\
\hline Austria & 1 & 0.2 \\
\hline Belize & 1 & 0.2 \\
\hline Bermuda & 1 & 0.2 \\
\hline Bolivia & 1 & 0.2 \\
\hline Bulgaria & 1 & 0.2 \\
\hline Cambodia & 1 & 0.2 \\
\hline cape Verde & 1 & 0.2 \\
\hline Colombia & 1 & 0.2 \\
\hline Congo, democratic republic of the & 1 & 0.2 \\
\hline Czech republic & 1 & 0.2 \\
\hline Eritrea & 1 & 0.2 \\
\hline French Guiana & 1 & 0.2 \\
\hline Georgia & 1 & 0.2 \\
\hline Honduras & 1 & 0.2 \\
\hline Indonesia & 1 & 0.2 \\
\hline Iraq & 1 & 0.2 \\
\hline jersey & 1 & 0.2 \\
\hline Kazakhstan & 1 & 0.2 \\
\hline
\end{tabular}




\begin{tabular}{l|ll}
\hline Kuwait & 1 & 0.2 \\
Lebanon & 1 & 0.2 \\
Madagascar & 1 & 0.2 \\
Malaysia & 1 & 0.2 \\
Mauritania & 1 & 0.2 \\
Mexico & 1 & 0.2 \\
Norway & 1 & 0.2 \\
Oman & 1 & 0.2 \\
Pakistan & 1 & 0.2 \\
Peru & 1 & 0.2 \\
Slovenia & 1 & 0.2 \\
Sudan & 1 & 0.2 \\
Thailand & 1 & 0.2 \\
Uganda & 1 & 0.2 \\
western Sahara & 1 & 0.2 \\
& 496 & 99.83 \\
\hline
\end{tabular}


Table A2: Summary Statistics

\begin{tabular}{l|lll}
\hline Variable & Obs & Mean & Std. Dev. \\
\hline Overedjob1 & 15005 & 0.17 & 0.38 \\
overskillj 1 & 15005 & 0.19 & 0.39 \\
male & 15005 & 0.38 & 0.49 \\
Labour exp & 13991 & 52.75 & 13.87 \\
age & 14543 & 30.08 & 3.85 \\
Humanities & 15005 & 0.20 & 0.40 \\
Social & 15005 & 0.30 & 0.46 \\
Science & 15005 & 0.12 & 0.32 \\
Engineering & 15005 & 0.16 & 0.37 \\
Unemploy hist & 15005 & 0.36 & 0.48 \\
immigrant & 15005 & 0.03 & 0.18 \\
Course employer & 15005 & 0.40 & 0.49 \\
Course prestige & 15005 & 0.35 & 0.48 \\
Vocational course & 15005 & 0.40 & 0.49 \\
fieldmatch $\sim$ & 15005 & 0.30 & 0.46 \\
fieldrelat ${ }^{\mathrm{w}}$ & 15005 & 0.54 & 0.50 \\
Hours & 14888 & 36.39 & 8.01 \\
R\&D Firm & 15005 & 0.40 & 0.49 \\
Size 50-99 & 15005 & 0.08 & 0.27 \\
Size 100-249 & 15005 & 0.10 & 0.30 \\
Size 250-999 & 15005 & 0.15 & 0.35 \\
Size 1000+ & 15005 & 0.37 & 0.48 \\
Public sector & 15005 & 0.43 & 0.50 \\
N of employers & 14439 & 2.34 & 2.22 \\
Supervisor & 15005 & 0.32 & 0.47 \\
Italy & 15005 & 0.10 & 0.30 \\
Spain & 15005 & 0.17 & 0.37 \\
France & 15005 & 0.07 & 0.26 \\
Austria & 15005 & 0.06 & 0.23 \\
Netherlands & 15005 & 0.15 & 0.36 \\
UK & 15005 & 0.08 & 0.26 \\
Finland & 15005 & 0.10 & 0.30 \\
Norway & 15005 & 0.11 & 0.31 \\
Portugal & 15005 & 0.02 & 0.15 \\
Belgium & 15005 & 0.07 & 0.25 \\
Germany & 15005 & 0.07 & 0.26 \\
\hline & & &
\end{tabular}


Lwage

Overednow:

Overedjob1:

Overskillnow:

Overskilljob1:

Male:

Labour exp

age:

Years HE:

Humanities:

Social:

Science:

Engineering:

Supervisor:

Fieldmatchnow:

Fieldrelatednow:

Course employer:

Course prestige:

Vocational course:

Hours:

R\&Dfirm:

Size 50-99:

Size 100-249:

Size 250-999:

Size 1000+:

Public sector:

$\mathrm{N}$ of employers:
Gross monthly earnings in main employment logged.

Dummy variable takes value 1 if overeducated in current job and zero otherwise

Dummy variable takes value 1 if overeducated in first job and zero otherwise

Dummy variable takes value 1 if overskilled in current job and zero otherwise

Dummy variable takes value 1 if overskilled in first job and zero otherwise

Dummy variable takes value 1 if Male and zero otherwise

Number of months employed since graduation

Age in years

Years spent in Higher Education

Dummy variable takes value 1 if main field of study was Humanities and zero otherwise

Dummy variable takes value 1 if main field of study was Social

Science and zero otherwise

Dummy variable takes value 1 if main field of study was Science and zero otherwise

Dummy variable takes value 1 if main field of study was Engineering and zero otherwise

Dummy variable takes value 1 if supervised staff members and zero otherwise

Dummy variable takes value 1 if current job matched exclusively to field of study and zero otherwise

Dummy variable takes value 1 if current job matched on own or a related field of study and zero otherwise

Dummy variable takes value 1 if employers were familiar with course and zero otherwise

Dummy variable takes value 1 if course was academically prestigious and zero otherwise

Dummy variable takes value 1 if course was vocationally and zero otherwise

Regular contract hours per week

Dummy variable takes value 1 if employed in a research intensive firm and zero otherwise

Dummy variable takes value 1 if employed in a firm with 50 to 99 workers and zero otherwise

Dummy variable takes value 1 if employed in a firm with 100 to 249 workers and zero otherwise

Dummy variable takes value 1 if employed in a firm with 250 to 999 workers and zero otherwise

Dummy variable takes value 1 if employed in a firm with over 1000 workers and zero otherwise

Dummy variable takes value 1 if employed in a public sector

organisation and zero otherwise

Number of employers since graduation 
